\title{
Mechanisms Underlying Performance Impairments Following Prolonged Static Stretching Without a Comprehensive Warm-up
}

Authors: David G. Behm¹, Anthony D. Kay², Gabriel S. Trajano ${ }^{3}$, Anthony J. Blazevich ${ }^{4}$

Institutions: ${ }^{1}$ School of Human Kinetics and Recreation, Memorial University of

Newfoundland, St. John's, Newfoundland and Labrador, Canada

${ }^{2}$ Sport, Exercise and Life Sciences, School of Health, The University of

Northampton, Northampton NN2 7AL, UK.

${ }^{3}$ Faculty of Health, School - Exercise and Nutrition Sciences, Queensland

University of Technology, Brisbane, Australia

${ }^{4}$ Centre for Exercise and Sports Science Research, Edith Cowan University, Joondalup Campus, Joondalup, WA 6027, Australia.

Corresponding Author: David G Behm, $\mathrm{PhD}$

School of Human Kinetics and Recreation, Memorial University of Newfoundland, St. John's, Newfoundland and Labrador, Canada, A1C 5S7

dbehm@mun.ca

Tel: $709-864-3408$

Fax: 709-864-3979

Running Title: $\quad$ Static Stretching Mechanisms

Conflict of Interest: The authors declare no conflict of interest with the contents of this manuscript 


\begin{abstract}
Whereas a variety of pre-exercise activities have been incorporated as part of a "warm-up" prior to work, combat, and athletic activities for millennia, the inclusion of static stretching (SS) within a warm-up has lost favour in the last 25 years. Research emphasised the possibility of SSinduced impairments in subsequent performance following prolonged stretching without proper dynamic warm-up activities. Proposed mechanisms underlying stretch-induced deficits include both neural (i.e. decreased voluntary activation, persistent inward current effects on motoneurone excitability) and morphological (i.e. changes in the force-length relationship, decreased $\mathrm{Ca}^{2+}$ sensitivity, alterations in parallel elastic component) factors. Psychological influences such as a mental energy deficit and nocebo effects could also adversely affect performance. However, significant practical limitations exist within published studies, e.g. long stretching durations, stretching exercises with little task specificity, lack of warm-up before/after stretching, testing performed immediately after stretch completion, and risk of investigator and participant bias. Recent research indicates that appropriate durations of static stretching performed within a full warm-up (i.e. aerobic activities before and task-specific dynamic stretching and intense physical activities after SS) have trivial effects on subsequent performance with some evidence of improved force output at longer muscle lengths. For conditions in which muscular force production is compromised by stretching, knowledge of the underlying mechanisms would aid development of mitigation strategies. However, these mechanisms are yet to be perfectly defined. More information is needed to better understand both the warm-up components and mechanisms that contribute to performance enhancements or impairments when SS is incorporated within a pre-activity warm-up.
\end{abstract}

Key words: flexibility; range of motion; warm-up; sport; muscle morphology; neural. 


$\begin{array}{ll}\text { Abbreviations } \\ \text { ECM } & \text { extracellular matrix } \\ \text { EMD } & \text { electromechanical delay } \\ \text { EMG } & \text { electromyography } \\ \text { E-reflex } & \text { exteroceptive reflex } \\ \text { GABA } & \text { gamma aminobutyric acid } \\ \text { GTO } & \text { Golgi tendon organ } \\ \text { H-reflex } & \text { Hoffman reflex } \\ \text { MEP } & \text { motor evoked potential } \\ \text { MTU } & \text { muscle tendon unit } \\ \text { MVC } & \text { maximal voluntary contraction } \\ \text { MVIC } & \text { maximal voluntary isometric contraction } \\ \text { NMES } & \text { neuromuscular electrical stimulation } \\ \text { PEC } & \text { parallel elastic component } \\ \text { PF } & \text { plantar flexors } \\ \text { PIC } & \text { persistent inward current } \\ \text { RNS } & \text { reactive nitrogen species } \\ \text { ROM } & \text { range of motion } \\ \text { ROS } & \text { reactive oxygen species } \\ \text { SS } & \text { static stretching } \\ \text { TMS } & \text { transcranial magnetic stimulation } \\ \text { TVR } & \text { tonic vibration reflex } \\ & \end{array}$

\section{Introduction}

Pre-activity preparations for work, combat, and sports have been evident for millennia. It is surmised that pre-activity warm-ups would have been essential for successful movement execution in boxing, martial arts, and wrestling, which have been practiced in eastern civilizations such as the Chinese, Japanese, Aleut and Mongolians since pre-historic times (Draeger 1969) because of the extreme positions, kicks and strikes used in these activities. Stretching was also prescribed as part of exercise to prevent illness by Hua Tuo, the Han Dynasty physician (104-208 CE) (Kunitz 2016). In western civilizations, ancient Egyptians and Greeks held athletic competitions (Kunitz 2016) that would also have necessitated some form of warm-up to ensure success and prevent injury (Behm 2018). Jaquet et al. (2015) highlighted that the thrusting actions of medieval armoured fighters required a great range of motion for the 
adduction/abduction of the shoulder and flexion/extension of the elbow. Hence, it is speculated that pre-exercise dynamic warm-up activities would have been predominant throughout history (Kunitz 2016), evolving into the mid-1 $9^{\text {th }}$ century as activities for recreation and health (e.g. Swedish Ling's gymnastics) and further morphing into dynamic and ballistic fitness and conditioning movements of the 1950s (e.g. 5BX exercise program for military personnel) (Orban 1962). Subsequently, during the 1960s and for approximately the next $30-40$ years, static stretching (SS) replaced ballistic and dynamic stretching as a predominant warm-up activity, in addition to purposeful task-specific warm-ups. The goal of SS was to increase range of motion (ROM), decrease injury incidence, and improve athletic performance (Young 2007; Young and Behm 2003).

However, research around the new millennium started to accumulate showing that SS might impair rather than enhance athletic performance (Behm et al. 2001; 2004; Fowles et al. 2000; Kokkonen et al. 1998; Power et al. 2004). As the reports of SS-induced performance deficits multiplied, professionals and practitioners increasingly replaced SS with dynamic stretching as the primary flexibility component of the warm-up (Judge et al. 2020). However, in the last decade several critical reviews have disseminated the idea that numerous limitations in study design within the SS literature may have biased the research findings underlying the shift away from SS. A number of reviews (Behm et al. 2016a; Behm and Chaouachi 2011; Chaabene et al. 2019; Kay and Blazevich 2012; Lima 2019) highlighted that prolonged periods of acute SS (e.g. $>60$ s per muscle group) generally induced significant and practically relevant deficits while shorter SS had trivial effects. In addition to excessive SS durations, there were also concerns relating to ecological validity in many studies. Behm et al. (2016a) documented that many SS studies did not employ a prior aerobic-based warm-up, did not include dynamic sport- 
specific activities after stretching, conducted the testing within 3-4 min of the experimental protocol (when longer periods are common in many sporting situations), and were influenced by possible nocebo effects associated with participant bias (i.e. sport science students who were taught or had read that SS impairs performance) (Bertolaccini et al. 2019; Blazevich et al. 2018; Janes et al. 2016). A number of recent studies have shown that when short- or moderate-duration ( $<60 \mathrm{~s}$ per muscle) SS is employed within a comprehensive task- or sport-specific warm-up, the effects on performance are typically trivial or even positive (Blazevich et al. 2018; Mascarin et al. 2015; Murphy et al. 2010; Reid et al. 2018; Samson et al. 2012).

Although both recent reviews and original investigations utilising appropriate durations of SS within a full warm-up have revealed significantly increased ROM with trivial or positive effects on performance, it is still commonly reported that an acute bout of SS impairs subsequent performance. A recent survey of 195 American soccer coaches reported that 134 coaches only used dynamic stretching, 35 used a combination of dynamic and SS, one coach used only SS and others used a variety of ballistic, proprioceptive neuromuscular facilitation and other techniques (i.e. foam rolling) during warm-up (Judge et al. 2020). The change in public perception and athletic practice is problematic as this change is likely a consequence of recommendations from research with limited ecological validity for athletic practice.

In contrast, prolonged SS is still prescribed for individuals with serious range of motion limitations, especially in rehabilitation and other clinical settings (Decoster et al. 2005). So there is still a need to develop interventions to reduce or mitigate the effects of prolonged SS when employed in isolation (i.e. without further warm-up or task practice). This would require a complete understanding of the mechanisms by which stretching affects force production, however, these are yet to be fully described. Thus, the objective of this narrative review is to 
highlight the existing and most recent literature on the effects of SS on subsequent performance with the major focus to examine the neurological, morphological, and psychological mechanisms underlying SS-induced performance alterations.

\section{Effect of Static Stretching (SS) on Physical Performance}

The position that static stretching could enhance muscle force production was borne out by the results of the limited research up to the 1990s. For example, Worrell et al. (1994) implemented four hamstrings stretches of $15-20 \mathrm{~s}$ each (60-80 s) and found improvements in leg flexion concentric and eccentric contraction torques of $8.5 \%-13.5 \%$ and $2.5 \%-11.2 \%$, respectively. However, results of research in the mid- to late 1990s led to the questioning of the legitimacy of the belief that SS could improve performance. Kokkonen et al. (1998) was one of the first studies to report SS-induced performance impairments when they found that 5 stretches performed for 6 repetitions of $15 \mathrm{~s}$ (90-s total per stretch) decreased knee flexion and extension torque by $7-8 \%$. A subsequent paper by Fowles et al. (2000) then triggered an avalanche of further research. They imposed 13 static plantar flexor (PF) stretches of $135 \mathrm{~s}$ each ( $\sim 30 \mathrm{~min}$ total stretching) and observed a $28 \%$ mean decrease in PF maximal voluntary isometric contraction (MVIC) force immediately post-stretch with a 9\% deficit still observed after 60 min. Behm et al. (2001) imposed a briefer, but still very long, 20-min SS on the quadriceps and found impairment in MVIC (12\%), electromyographic (EMG) activity (20\%) and evoked twitch force (12\%) after stretching. However, many researchers have investigated the impact of much shorter

periods of SS. A review by Behm and Chaouachi (2011), recommended that stretching durations of $<90$ s would tend to produce trivial magnitude performance impairments. Later, Kay and Blazevich (2012) and Behm et al. (2016a) concluded that stretches $<60$ s would produce trivial 
performance impairments, whereas the risk of longer periods of stretch was significantly greater. Behm et al. (2016a) found that strength impairments in studies incorporating $<60 \mathrm{~s}$ of SS per muscle were $2.8 \%$ compared to a $5.1 \%$ reduction when using $\geq 60 \mathrm{~s}$ of SS. With SS studies incorporating power- or speed-based variables, mean power impairments averaged $2.6 \%$ with $\geq 60 \mathrm{~s}$ of SS. Studies that used $<60 \mathrm{~s}$ of SS showed trivial power or speed performance deficits, averaging only $0.15 \%$. Since these reviews were published, numerous studies have directly compared the effects of shorter (e.g. $<60 \mathrm{~s}$ ) versus longer ( $\geq 60 \mathrm{~s}$ ) periods of stretch on physical performance outcomes and generally found that impairments existed when stretches lasted $\geq 60 \mathrm{~s}$ (Palmer et al. 2019; Reid et al. 2018; Vieira 2019). Notwithstanding this general finding, some research has suggested that the cumulative duration of SS may also impact subsequent performance. For example, Brusco et al. (2018) reported countermovement jump height deficits following $30 \mathrm{~s} \mathrm{SS}$ of multiple muscles (calves, hamstrings, gluteus maximus and quadriceps). Thus, several recent reviews (2011 - 2016) as well as intervention studies highlighted that performance impairments were more commonly associated with $>60 \mathrm{~s}$ of SS, although some cumulative effect might be conferred when multiple muscles are stretched for a reasonable (as yet undefined) time. Despite this, it can be questioned whether publishing sports scientists took notice, or governing bodies altered/reversed position stands or exercise prescription recommendations that supported the removal of static stretch during a warm-up. One benefit of studying longer durations of stretch, which tend to produce significant losses in muscle function, is that it more easily allows for the study of the mechanisms underpinning the loss. However, it should be clarified that these studies have practical implications for only a small number of individuals (who perform long durations of stretch with little/no other warm-up and then produce maximal-effort tasks). Both authors and readers should thus be clear that the results of studies 
using these designs may be misinterpreted or mistakenly applied in athletic, rehabilitation or fitness circumstances.

\section{PLACE TABLE 1 APPROXIMATELY HERE}

\section{Search Strategy}

A literature search was performed by the co-authors using PubMed, SPORTDiscus, Web of Science, and Google Scholar databases. The topic was systematically searched using a Boolean search strategy with the operator "AND" and keywords related to stretching, flexibility, range of motion, AND measures of performance (i.e. strength, power, endurance). Based upon our knowledge of the area we also contributed additional studies which we had knowledge of but were not picked up in systematic searches; further, we conducted searches of our personal computer databases for related articles.

Search Results

Table 1 reports a sample of 44 studies published since the Behm et al. (2016a) review that examined the effect of SS on performance. The table highlights that some of the methodological difficulties presented above are still prevalent in the literature. First, as with many areas of sports science research, female participants were under-represented ( $25.5 \%$ of the total sample). Also, only two of 27 studies investigated youth ( $<18$ years of age) and no studies examined participants over 40 years of age. Therefore, potential effects of sex and age on the stretch-induced loss of muscle force cannot be clearly described as yet. Second, several issues relating to study validity were highlighted by Behm et al. (2016a). One issue was the importance of a complete warm-up involving dynamic muscular activities both before and after SS. However, prior aerobic or dynamic warm-up activities were included in only $50 \%$ of the studies published since 2016, and only four studies (11.3\%) included dynamic activities post-SS. The 
four SS studies in which a full warm-up was included and stretches were held for $<60 \mathrm{~s}$ per muscle group reported either trivial effects on performance (Blazevich et al. 2018; Reid et al. 2018) or small performance improvements (Murphy et al. 2010; Samson et al. 2012). In these four studies, multiple muscle groups were stretched resulting in an accumulation of more than 60 s of total stretching, yet with comprehensive warm-ups there was still no evidence of performance impairments. The majority of studies (59.1\%) imposed tests less than 5 min poststretching, even though longer periods usually separate athletic activities (i.e. training session, competition) from SS, during which time further sport-specific dynamic activities are completed and athletes return to dressing room for equipment adjustments, pre-game coach's strategy and motivational talks, and other pre-match activities (Behm et al. 2016a). Regardless, the overall results of these 27 studies reveal a mean moderate magnitude (8.04\%; $\mathrm{d}=0.55)$ ROM increase and a mean small magnitude $(-1.5 \%$; $\mathrm{d}=0.36)$ post-SS performance decrement. Hence, even though research protocol limitations persist, which likely amplify the stretch-induced performance loss but also limit ecological validity under many conditions, SS-induced performance decrements were observed to be small on average in studies after 2016.

Based on the above arguments, it appears important to consider that stretch-induced performance decrements are likely to be negligible when SS is of short or moderate duration (e.g. $<60 \mathrm{~s}$ per muscle), at least when only a few muscles are stretched and/or a complete physical preparation (warm-up) is performed between the SS and exercise or sporting task. It is also notable that, in contrast to the commonly reported performance impairments, five studies that reported strength decrements at short muscle lengths $(-10.2 \%)$ observed moderate strength improvements at the longest muscle lengths tested (+2.2\%) (Balle et al. 2015; Herda et al. 2008; McHugh and Nesse 2008; McHugh et al. 2013; Nelson et al. 2001b). Performance enhancement 
at longer muscle lengths could be of practical importance since muscle strain injuries are more likely to occur with the muscle at a longer rather than shorter length (Behm et al. 2016a; Heiderscheit et al. 2010) and many sporting activities require force production at longer muscle lengths. Furthermore, SS-induced performance enhancement has also been reported during stretch-shortening activities that involve prolonged transition (eccentric to concentric) phases such as running at slower velocities (Godges et al. 1989) and the rebound bench press (Wilson et al. 1992).

Regardless of the background of evidence that properly-programmed acute SS may not be associated with performance decrement, or may moderately enhance performance, longer durations of SS are needed by some individuals in some sports, or in some clinical and rehabilitation settings. In these cases, there remains a possibility of stretch-induced performance decrement that could impact functional performance and clinical/rehabilitation outcomes, both acutely and in the longer term. When longer durations of SS are necessary, athletes, coaches and clinicians may have to consider the potential trade-offs or concessions between substantial increases in flexibility and performance decrements. Future applied stretch research should investigate interventions that would allow more prolonged SS without inducing impairments (i.e. alternative warm-up strategies, timing, nutritional and pharmaceutical aids). In order to develop these interventions that might minimise the effects of SS on muscle functional loss it is first important to determine the mechanisms that underpin the phenomenon. Secondly, it is of additional interest to determine which mechanisms are involved to counterbalance performance impairments when a full warm-up is incorporated.

\section{Neural Responses to Static Stretching (SS)}


Changes in Muscle Activity (Electromyography: EMG)

The EMG signal broadly reflects the extent of muscle activation and is a composite signal that is influenced by both central and peripheral components of the neuromuscular system including muscle conduction velocity, motor unit recruitment and firing frequency (rate coding), motor unit synchronisation, and muscle fibre action potential amplitudes and durations (Farina et al. 2002; Hagg 1992). Stretching can influence sensory (afferent) inputs, modulating both supraspinal (brain) and spinal excitability (Matthews 1981). However, the effect of SS on muscle activation capacity as measured by EMG activity is often contradictory throughout the SS literature. EMG decrements have been reported after a variety of SS durations when tested either immediately (<1 min) (Babault et al. 2010; Behm et al. 2019; Marchetti 2017; Ryan et al. 2014; Trajano et al. 2013) or 10 (Behm et al. 2001), 15 (Fowles et al. 2000) or 60 min (Avela et al. 1999) post-SS. In contrast, there were no significant EMG reductions after SS protocol durations of 30-120 s (Caldwell et al. 2019; Palmer et al. 2019; Power et al. 2004; Reid et al. 2018), $180 \mathrm{~s}$ (Kay and Blazevich 2009a), or 5 (Mizuno et al. 2014), 9.2 (Herda et al. 2008) or $10 \mathrm{~min}$ (Barbosa et al. 2019). Mixed results were also reported by Damasceno et al. (2014) who recorded both increased biceps femoris EMG activity and no change in the vastus medialis or gastrocnemius EMG during a $3-\mathrm{km}$ running time trial following $3 \times 30 \mathrm{~s}$ of SS. In a series of studies, Trajano et al. (2013; 2014a; 2019) monitored EMG immediately, 15 and 30 min post-SS and reported impairments immediately post-SS but not at the latter testing points, suggesting an initial impairment but reasonably rapid recovery of muscle activation. In addition to $\mathrm{M}$ wavenormalised EMG amplitudes, Trajano et al. (2013) measured the V-wave amplitude (variant of the H-reflex providing evidence of voluntary drive to the motoneurons) and found that both EMG and V-wave changes were correlated with the decrease and subsequent recovery of MVC 
force. Correlations between SS-induced reductions in EMG amplitude and MVC force have been also reported in other studies (Fowles et al. 2000; Kay and Blazevich 2009a; Trajano et al. 2017). While SS-induced influences upon the EMG signal may be relatively transient, the muscle action potential wave (M-wave) amplitude and duration (reflects changes in electrode recording volume) can be affected by more persistent peripheral changes such as exerciseinduced changes in intramuscular and interstitial acidity, electrolyte balance (i.e. $\mathrm{Na}^{+}, \mathrm{K}^{+}, \mathrm{Ca}^{2+}$ ), contraction-induced ischaemia, electrode recording volume, and other factors (Dimitrova and Dimitrov 2003). SS elicits vasoconstriction reducing blood flow to the stretched muscle (Venturelli 2019) due to a systemic increase in sympathetic neural tone (Cui et al, 2006) from the stress induced by SS on the mechano- and metaboreceptors (Venturelli 2017). As this SSinduced vasoconstriction is followed by a hyperaemic response, the muscles supply of oxygen, substrates, and removal of $\mathrm{CO}_{2}$ and metabolites can vary substantially, modulating energy dependent processes such as the muscle action potential's $\mathrm{Na}^{++} / \mathrm{K}^{+}$pump. Furthermore, M-wave amplitudes change when joints are passively rotated, possibly because of changes in muscle architecture changing the relative position of the electrodes relative to the muscle fibre (Frigon et al. 2007; Vieira et al. 2017). Therefore, small changes in muscle length (or width) caused by stretching could change both M-waves and EMG amplitudes. Also, changes in recording conditions (e.g. changes in electrode-skin impedance with sweat for example, electrode movement) could also affect the recordings. Hence in addition to the possibility of electrode displacement with stretching, it is important to normalize the EMG signal to the present circumstances of the M-wave. Thus, evidence of extensive, full motor unit depolarisation (activation) throughout the muscle may be obscured by an EMG signal that is depressed by peripheral changes, as can be observed by measurement of the M wave. Secondly, the EMG- 
force relationship is more commonly described by a curvilinear slope (Perry and Bekey 1981; Solomonow et al. 1990) and thus incremental changes in EMG do not translate directly into similar changes in muscle force or power. Muscle activation measures, including EMG activity (Perry and Bekey 1981; Solomonow et al. 1990) and the interpolated twitch technique (in which stimulation is evoked during and after a voluntary contraction to determine the extent of muscle inactivation)(Behm and St-Pierre 1997) tend to plateau at maximal and near maximal muscle contraction levels, suppressing evidence of stretch-induced neural deficits with strength or power testing. Thus, this muscle activation-force plateau may not allow small changes in activation to be detected during near-maximal muscle exertions. The conflicting EMG changes among the many SS studies due to the aforementioned variables (i.e. EMG-force curvilinear relationship, peripheral effects on the $\mathrm{M}$ wave characteristics) prevents a conclusive statement relating to the effect of SS on EMG, and suggests the possibility that surface EMG recording might lack the sensitivity to be a strong and consistent proxy for central (neural) drive measurement. However, when muscle activation signals were normalized to the M wave or the MVC, there is more consistent observations of acute reductions in EMG (Blazevich et al. 2012a; Pulverenti et al. 2019; 2020), Hoffman (H-) reflexes (Budini et al. 2018b; Guissard et al. 2001) as well as stretchtraining induced decreases in normalized H-reflexes (Blazevich et al. 2012b).

Reflex-induced EMG activity may also influence ROM. Guissard and Duchateau (2006) suggested that the maximal passive joint ROM is strongly associated with the degree of muscle resistance induced by tonic reflexes. Whereas dynamic movements and dynamic stretching tend to increase facilitatory reflex responses (Behm 2018), SS is purported to reduce facilitatory reflex (excitatory) activity (Behm et al. 2001; 2004; 2016a; Behm and Chaouachi 2011). While this reduced reflex activity may help enhance muscle relaxation, and thus speculatively 
contribute to enhanced ROM, it might alternatively be expected to negatively impact the ability to activate the motoneurones and thus inhibit maximal activation of the stretched muscles. However, reflex effects are suggested to be more transient (Guissard et al. 1988), lasting only until the stretch is released or for seconds after, and thus probably contribute less significantly to performance impairments than changes in other neuromuscular properties.

\section{Motoneurone Excitability (Hoffman (H) reflex amplitude)}

As we have emphasised, while long durations of SS can negatively impact performance, the reflex inhibition may be brief. The H-reflex is a proxy measure of the afferent excitability of the spinal motoneurone (Schieppati et al. 1986; Zehr 2002). It attempts to mimic a stretch reflex with the stimulation of a peripheral sensory nerve, and thus reflects the excitation or inhibition of the reflex circuit affecting the ability to produce force. For example, Avela et al. (1999) reported that 1 hour of passive triceps surae SS reduced MVC force (23.2\%), EMG (19.9\%), and H-reflex activity (43.8\%) immediately following SS, but no significant effects were observed at 15 and 30 min post-SS. Guissard et al. (1988) reported that SS-induced H-reflex deficits recovered quickly and were primarily only limited to the duration of the stretch. When implementing $30 \mathrm{~s}$ of SS, Budini et al. (2018a) reported no significant H-reflex impairments.

In the few studies in which H-reflex amplitudes were found to be impaired by SS, the cause was speculated to be due to a reduction in excitatory drive from the Ia afferents due to decreased resting muscle spindle discharge (disfacilitation) resulting from an increase in compliance within the muscle-tendon unit (Avela et al. 1999). Guissard et al. (2001) compared the activity of H-reflexes and exteroceptive (E-) reflexes (receptors primarily located in cutaneous/ skin tissue) during stretching and were able to delineate that the H-reflex (pre- 
synaptic mechanisms) was attenuated with small stretching amplitudes whereas E-reflex (postsynaptic mechanisms) inhibition was predominant during large amplitude stretches. Pre-synaptic inhibition involves the release of inhibitory neurotransmitters that inhibit $\mathrm{Ca}^{2+}$ channels, reducing glutamate (excitatory neurotransmitter) release from nearby synapses (Stein 1995), whereas postsynaptic inhibition involves the release of neurotransmitters from the post-synaptic neurone that alters membrane conductance or membrane potentials (Stein 1995). Nonetheless, immediately following the cessation of stretching the $\mathrm{H}$ - and E-reflexes returned to their baseline values (Guissard et al. 2001). In contrast to their study in which stretch-induced H-reflex inhibition was not detected, another Budini et al. (2018b) study reported two stages of H-reflex inhibition with primarily post-activation depression of Ia afferents caused by maximal passive ankle dorsiflexion stretching within the first $18 \mathrm{~s}$, then from 21-30 s there was a weaker post-activation depression, with inhibition from type II afferents or post-synaptic inhibition. However, there is evidence that H-reflex decrements may not be directly associated with performance changes. Stevanovic et al. (2019) found that both the H/M ratio (-20.5\%) and vertical jump height (-2.6\%) decreased 8 min following SS (6-min stretch duration), however when basketball-specific exercises were completed post-SS, vertical jump height was significantly increased $3.0 \%$ above baseline even though the H/M ratio decreased further (-30.2\%). The relationship between H-reflex inhibition and performance impairments are somewhat conflicting. Although Stevanovic (2019) reported 8 min of H-reflex inhibition after stretching, most other studies report H-reflex inhibition during the stretch with a rapid return to resting values after stretching (Avela et al. 1999; Guissard et al. 1988; 2001). However, these post-stretch H-reflex measurements were taken with the muscle at rest (relaxed) and may not reflect changes that might occur during muscle contraction. In summary, based on the few available studies, SS-induced H-reflex depression may dissipate soon 
after stretching and thus is unlikely to considerably negatively impact subsequent performance. Nonetheless, muscle spindle discharge is not the only reflex mechanism that may affect subsequent performance.

\section{Exteroceptive (E) Reflexes}

Myofascia and skin are densely innervated by sensory receptors (Schleip 2003a; 2003b) that are sensitive to skin stimulation, tangential forces and lateral stretch (Kruger 1987). Ereflexes are initiated by cutaneous (skin) receptors that have polysynaptic innervations to motoneurones (Jenner and Stephens 1982; Kearney and Chan 1999), which contribute to sympathetic inhibition (i.e. muscle relaxation) (Wu et al. 1999). Reflex-induced reductions in sympathetic drive can contribute to overall relaxation by decreasing muscle tone, heart rate and blood pressure (van den Berg and Cabri 1999; Wu et al. 1999). Small amplitude SS had no significant inhibitory effect on the E-reflex (Delwaide et al. 1981), whilst larger ROM stretches decreased both H- and E-reflexes similarly (Guissard et al. 2001). Nonetheless, this depression lasted only several seconds after stretching was ceased, and therefore should not directly contribute to ongoing losses of activation detected minutes after stretch cessation. Fowles et al. (2000) speculated that types III (mechanoreceptor, e.g. pressure, vibration) and IV (nociceptor, i.e. pain, temperature) afferents might also contribute to motoneurone inhibition. According to the results of Guissard and Duchateau (2006) in humans as well as in animal (cat) studies (Cleland et al. 1990; Cleland and Rymer 1990; 1993), joint and cutaneous receptors have not been found to provide strong inhibition of the motoneurones during small-amplitude stretches and play only a small role with larger amplitude stretches. Hence similar to the H-reflex, E-reflex 
inhibition may occur during large amplitude stretches but desist soon thereafter and thus would not substantially contribute to subsequent performance impairments.

\section{Golgi Tendon Inhibition}

Stretching to, or near the point of, discomfort is typically perceived to place considerable stress and strain upon the musculotendinous unit. Since Golgi tendon organs (GTO; type Ib afferents) respond to musculotendinous tension (Houk et al. 1980), it could be assumed that the tension might induce GTO inhibition and thus promote muscle relaxation (i.e. lower muscle tone). The autogenic inhibition (GTO reflex) reflex is di-synaptic, inhibiting the same muscle group that provided the tension (Khan and Burne 2009). Walshe and Wilson (1997) suggested that increasing musculotendinous unit stiffness might increase GTO inhibition. However, Edin and Vallbo (1990) monitored microneurography, EMG and torque signals during ramp and hold stretches and reported that GTOs (Ib afferents) were insensitive to the stretch-induced tension, even though muscle spindle afferents (Ia and II) responded rapidly to stretch. However, as for the effects of stretch-induced force, GTO effects persist for only approximately 60-100 ms after cessation of stress, the duration of these inhibitory effects does not appear to be sufficient to influence subsequent muscle performance (Houk et al. 1980; Trajano et al. 2017).

\section{Corticospinal excitability / inhibition}

Stretch-sensitive muscle spindles are innervated by both type I and II sensory (afferent) neurones (Prochazka and Ellaway 2012). These fibres project to structures within the brain such as the somatosensory and the primary motor cortices (Phillips et al. 1971; Rathelot and Strick 2009). Additionally, afferent neurones innervating skin and joint receptors, and which are 
activated during stretch, project to the somatosensory cortex and thalamus, which could also influence motor output from the primary motor cortex (Canedo 1997). Therefore, it has been speculated that changes in cortical circuits could be involved in the force loss observed after moderate-duration passive stretch (Trajano et al. 2017).

To date several studies have used transcranial magnetic stimulation (TMS) to investigate the possible effect of stretching on motor cortex excitability and the strength of its projection to motoneurones with conflicting results. When applied to the motor cortex at an intensity above motor threshold, TMS elicits a motor evoked potential (MEP) in the target muscle that is reflective of corticospinal excitability. Studies that have measured MEP amplitudes when the muscle is at rest (no voluntary contraction) after passive stretching have reported no significant changes, suggesting a lack of change in corticospinal excitability (Budini et al. 2017; 2019; Pulverenti et al. 2019). In particular, Pulverenti et al. (2019) reported a significant reduction in maximal force after stretching without reductions in MEP amplitude and, perhaps more importantly, no associations between individual variations in MEP responses and the magnitudes of reduction in maximal force. However, several studies have measured post-SS MEP amplitudes during voluntary contractions of various intensities and obtained different results. MEPs were unchanged when measured during contractions at maximum (Pulverenti et al. 2019) and 20\% of maximum (Pulverenti et al. 2020) after 5 min (5 sets of 60 s) of intense passive stretching, but increased when measured during a 30\% contraction after $100 \mathrm{~s} \mathrm{(5} \mathrm{sets} \mathrm{of} 20 \mathrm{~s}$ ) passive stretching (Opplert et al. 2020). It is difficult to reconcile these findings because different stretching protocols and measurement methods were used, but the current evidence indicates that SS has minimal effect on corticospinal excitability, and certainly does not appear to reduce it. Thus, 
there is currently no evidence to support the hypothesis that SS-induced force reductions might be explained by a reduction in corticospinal excitability.

The cortical silent period (an interruption of voluntary muscle contraction) observed when a single TMS pulse is applied to the motor cortex during a voluntary contraction, might also reveal cortical mechanisms underpinning stretch-induced force loss. This silent period duration is believed to be largely caused by the activation of gamma aminobutyric acid (GABA) inhibitory interneurones within the motor cortex by the TMS pulse and is usually indicative of intra-cortical inhibition. Three studies have measured the cortical silent period after SS, but no changes were detected during maximal contractions (Pulverenti et al. 2019) or those performed at 20\% (Pulverenti et al. 2020) or 30\% (Opplert et al. 2020) of maximum. These findings suggest that intra-cortical inhibition, measured as the cortical silent period, is not affected by passive stretching and is not currently a candidate explaining post-SS force losses.

\section{Motoneurone Responses}

In addition to the $\mathrm{Na}^{+}$-based current inflow that occurs as action potentials traverse the motoneurones, the dendritic regions of motoneurones have an important intrinsic mechanism for amplifying and prolonging the normal synaptic input they receive (e.g. from supraspinal centres and reflex pathways) by allowing a persistent inward current (PIC) flow through specialised $\mathrm{Na}^{+}$ and $\mathrm{Ca}^{2+}$ channels resulting in sustained depolarization (Binder et al. 2020). These PICs are greatly enhanced in the presence of monoamines such as serotonin and noradrenaline, which are released in the spinal cord by nerves emanating from brainstem nuclei, and are capable of enhancing motor output by up to 5-fold (Lee and Heckman 2000). This amplification of normal drive to the muscle is in fact fundamental to the capacity for motoneurones to fire at the high 
frequencies necessary to produce maximal and near-maximal levels of force. In the absence of these PICs, and neuromodulatory input from serotonergic and noradrenergic neurones, motoneurones would scarcely produce $40 \%$ of their maximal normal output (Heckman 1994). Therefore, PICs play an essential role in normal motor behaviour and particularly in our ability to produce rapid and high levels of muscular force.

One hypothesis that has been recently advanced (Trajano et al. 2017) is that SS might affect PIC-dependent amplification of central drive to the muscle, which would consequently reduce maximal force capacity. Indirect evidence to support this hypothesis originated from an experiment in which tonic vibration reflexes (TVRs) caused by tendon vibration were elicited before and after 5 min of passive stretching (Trajano et al. 2014b). TVRs elicit involuntary contractions via steady stimulation of the Ia reflex loop. The contractions evoked by bursts of neuromuscular electrical stimulation (NMES; $5 \times 2$-s bursts, $20 \mathrm{~Hz}$ frequency, $20 \% \mathrm{MVC}$ ) superimposed over the tendon vibration display features that are consistent with the initiation of PICs, including ongoing (i.e. self-sustained) motor unit firing after both vibration and NMES are ceased, inhibition of responses when the antagonist muscle is at long muscle length (inducing reciprocal inhibition), and the continuous increase in muscular force in response to the repetitive activation (i.e. warm-up effect) (Binder et al. 2020). Interestingly, all of these parameters were reduced immediately markedly after 5 min of passive stretching, partially recovered by 5 min, and fully recovered by 10 min after stretching (Trajano et al. 2014b). This time course of both reduction and recovery closely matches that which is observed in other experiments with similar stretching protocols (Pulverenti et al. 2019; 2020; Trajano et al. 2014a). These data provide some early evidence that stretch-induced PIC reductions might at least partly underpin the loss of force, and their recovery might be also important for the recovery of force. However, additional 
experiments with more robust, or direct, techniques are necessary to confirm this hypothesis. In the absence of other candidates for the post-SS loss of neural drive, assessments of the effects of SS on PICs are clearly warranted.

\section{Summary of neural mechanisms}

As summarised in Table 2, although many stretching studies attribute performance impairments to neural inhibition, current evidence is inconsistent. While tonic reflexes may increase muscle tone and contribute to resistance to movement, SS effects on EMG activity is conflicting, with both decreases and no change reported. Alterations in neuromuscular activation as measured by EMG activity may be obscured by peripherally induced modifications to the muscle action potential as well as the curvilinearity of the EMG-force relationship. Hence, EMG and reflex activity normalized to the $\mathrm{M}$ wave tend to present a more consistent decrement with stretching. Whereas inhibitory inputs from proprioceptive structures (i.e. H-reflex: Ia afferents and Golgi tendon organ: $\mathrm{Ib}$ afferents) can reduce facilitatory reflex activity, the duration of their effects tends to be too transient to meaningfully affect subsequent performance. However, stimulation of exteroceptive reflexes may aid in the suppression of excitatory sympathetic nervous activity contributing to a more relaxed state and less resistance to movement. The literature to date generally indicates that corticospinal excitability and intracortical inhibition (silent period) are not substantially affected by stretching, however reduced strength of PICs at the motoneurone dendrites could be adversely affected and contribute to force output deficits. Thus, despite the considerable evidence for reductions in neural drive underpinning the stretchinduced force loss, the exact mechanism/s causing the effect remain elusive. 
PLACE TABLE 2 APPROXIMATELY HERE

\section{Morphological responses to static stretching}

\section{Muscle and tendon stiffness alterations}

As the neuromuscular responses to stretch vary between studies and may not completely explain the immediate (Kay and Blazevich 2008; McBride et al. 2007; Power et al. 2004) or prolonged (Fowles et al. 2000; Trajano et al. 2014a) reductions in force after stretching in all cases, alternative mechanical and/or physiological mechanisms associated with post-SS force losses should be considered. One hypothesis is that changes in the stiffness of either contractile or passive elastic elements within the MTU may compromise force transmission and/or alter in vivo sarcomere dynamics during contraction, and thus impact the external force produced. For some joints, reductions in the slope of the passive moment-angle curve, which are considered to reflect changes in whole MTU stiffness, have been reported after acute SS (Kay and Blazevich 2009b; Kubo et al. 2001; Magnusson et al. 1996a), as reported in our previous review (Behm et al. 2016a). Since 2016, a further 14 studies have examined the acute effects of SS on force output and MTU stiffness. Six studies targeted the knee flexors and all reported significant reductions in MTU stiffness, however only studies imposing longer duration (3-5 min) stretches reported concomitant reductions in peak isometric force production (Hatano et al. 2019; Kataura et al. 2017; Matsuo et al. 2019), with no reduction in peak isometric (Palmer et al. 2019; Palmer and Thiele 2019) or concentric (Takeuchi and Nakamura 2020) force following shorter duration (20120 s) stretches. Similar findings were reported in the plantar flexors, with seven studies reporting reductions in MTU stiffness but with reductions in force generally reported only after longer-duration (2.5-5.0 min) (Bouvier et al. 2017; Konrad et al. 2019; Longo et al. 2017; 
Opplert et al. 2016) but not shorter-duration (2-3 min) stretches (Konrad et al. 2017a;b; Konrad and Tilp 2020a). Also, one study reported reductions in MTU stiffness lasting at least 10 min but reductions in force lasting only $5 \mathrm{~min}$ (Konrad et al. 2019), and another study employed shorterduration stretching (60 s) and reported no change in stiffness or muscle force (Konrad and Tilp 2020b). Finally, to our knowledge no studies directly assessed the relationship between changes in stiffness and changes in muscle force production, so a direct stiffness-muscle force link has not been established. These findings are consistent with the research conducted before 2016, in which only longer durations of stretch were associated with both peak force and MTU stiffness reductions and that associations between changes in MTU stiffness and muscle force after SS were weak. Thus, the data conclusively show that the factors influencing passive whole MTU stiffness do not substantially influence maximal voluntary muscle force production in the muscles studied. This makes sense given that (i) active and passive stiffness are unrelated when measured in ex vivo experiments (Prado et al. 2005), (ii) active muscle stiffness (i.e. responses to stiffness properties measured in humans during dynamic muscle contraction, e.g. by measuring oscillation responses to brief perturbations) is not related to passive MTU stiffness measured in muscle groups such as the ankle plantar flexors (Hunter and Spriggs 2000) or knee flexors (Blackburn et al. 2004), and (iii) reductions in passive MTU stiffness have been observed without changes in active stiffness after an acute bout of static plantar flexors stretching (Hunter 2001). The effects of stretching on active muscle mechanical properties after SS, therefore, cannot be inferred from measurements of passive stiffness.

Nonetheless, alterations in whole MTU stiffness may be negligible even when decreases in muscle (and fascicle) stiffness are clearly detectable (Blazevich et al. 2012a; Konrad et al. 2019). Several studies have detected changes in plantar flexor muscle stiffness, measured as the 
change in the passive muscle force-length relationship, without changes in tendon stiffness after 1-5 min of SS (Kay and Blazevich 2009a; Kay et al. 2015; Konrad et al. 2017a;b; Morse et al. 2008; Nakamura et al. 2011); however, it is not yet clear how stiffness is altered in other muscles, and no studies examined relationships between changes in muscle stiffness and changes in force production. Nonetheless, a reduction in tendon stiffness was observed when longer SS durations were used (10-20 min)(Kato et al. 2010; Kubo et al. 2001), suggesting that the tendon may be influenced by long stretch durations, although this may be influenced by the measurements being taken at the fascicle-aponeurosis junction which then allows changes in muscle stiffness to possibly contribute to the changes in 'tendon' stiffness. Tendon stiffness decrease may be expected to reduce muscle forces by reducing muscle length during contraction (Mayfield et al. 2016) or inducing a shortening-induced force depression, i.e. reduction in the force produced at a given muscle length that results from shortening immediately prior to the muscle reaching that muscle length (Raiteri and Hahn 2019). However, since short- and moderate-duration stretching do not significantly alter tendon stiffness, these phenomena are unlikely to be relevant to the stretch-induced force loss. Furthermore, post-SS force losses may be observed even when the muscle generates tension at the same length after stretching (Kay and Blazevich 2009b), yet force losses are not always observed even in cases where tendon stiffness is reduced (Kubo et al. 2001). Therefore, whilst changes in muscle-specific stiffness may temporally relate to changes in force production, a direct link has yet to be shown and changes in tendon stiffness do not appear to be associated with muscle force reductions. Thus, whilst further research is required to investigate possible links between changes in passive muscle mechanical properties and changes in active force production after stretching, there is little current evidence that changes in MTU stiffness directly influence the post-SS force decrement. 
Intramuscular connective tissue responses

Passive and active muscle stiffness measurements reflect mechanical properties of very different structures. As the parallel elastic component (PEC; including the endo-, peri- and epimysia) is literally in parallel with the contractile component, it is commonly considered to be unloaded during muscle contraction (MacIntosh and MacNaughton 2005; Rode et al. 2009). Thus, its contribution to muscle stiffness during active muscle contraction should be negligible. However, the PEC plays a significant role in resisting muscle lengthening during passive stretch (Gillies and Lieber 2011; Prado et al. 2005). Muscles contain a large amount of collagenous perimysial tissue in particular (Purslow 1989), which is thought to contribute significantly to the muscle's stretch resistance (Borg and Caulfield 1980; Purslow 1989; Williams and Goldspink 1984). Given that muscle stretching may acutely reduce passive muscle stiffness, it is likely that stretching affects the mechanical properties of the PEC itself. Consistent with this, both reduced MTU stiffness and increased electromechanical delay (EMD) have been concomitantly observed after SS (Costa et al. 2010; Hirata et al. 2016; Taniguchi et al. 2015). EMD comprises both electrochemical and mechanical components (Rampichini et al. 2014), and although lengthening of both components is reported immediately following SS (Esposito et al. 2011; Longo et al. 2017), the electrochemical component appears to recover rapidly whereas the mechanical component, thought to strongly reflect PEC stiffness, often remains impaired for many minutes after stretch and is consistent with the temporal recovery of MTU stiffness (Esposito et al. 2011). Nonetheless, only indirect evidence for the effect of stretching on the PEC has been presented, so it is not yet explicitly clear whether stretching can trigger changes in the PEC that persist after the stretch is completed. 
Any change in PEC stiffness might be functionally relevant. Although changes in PEC stiffness should not directly affect muscle force by reducing the passive component of the total force (i.e. total force $=$ passive + active) under most conditions (MacIntosh and MacNaughton 2005; Rode et al. 2009), there are two potential mechanisms by which PEC stiffness might influence muscle force. First, evidence exists in both animal models (Huijing 1999; Huijing et al. 2007) and in human muscles (Bojsen-Moller et al. 2005) that forces produced within muscle fibres are transferred to the skeleton via the PEC. Reductions in PEC stiffness could therefore affect the efficiency of force transmission within the muscle, and to the external tendon and skeleton (Huijing 1999; Huijing and Baan 2003). These possibilities are yet to be explicitly explored. Second, axial (longitudinal) fibre shortening during contraction is also accompanied by radial fibre (transverse) expansion since muscles (and fibres) are relatively isovolumetric during contraction (Baskin and Paolini 1967). Therefore, some parts of the PEC must be stretched during muscle shortening (including during 'fixed end' isometric contractions) and thus its properties may influence shortening capacity (Roberts et al. 2019). Also, fibres in most muscles are not arranged in line with the muscle's longitudinal axis but are oriented at an angle (the pennation angle), so stretch and shortening of muscle may cause some stretch/shortening in the PEC, and thus the fibres and muscle, both axially and radially. Both axial and radial forces will influence the amount of fibre rotation during contraction and hence the ratio of muscle-to-fibre length change (or velocity) (Eng et al. 2018; Roberts et al. 2019). This ratio, i.e. the "gear" in which the muscle operates, influences muscle force and velocity characteristics (increased rotation [i.e. gear] increases velocity at peak power). Current evidence suggests that the mechanical properties of intramuscular connective tissues contribute to the magnitude of fibre rotation (Eng and Roberts 2018; Holt et al. 2016), and thus the muscle's gear, and therefore must 
influence the force (and power)-velocity properties of the muscle (Roberts et al. 2019). Thus, based on this current view of the role of the PEC, changes in the PEC in response to muscle stretching may theoretically influence active muscle force production. However, it is not clear whether these would increase or decrease muscle force production, or whether it would vary depending on the contraction type (e.g. isometric/concentric vs. eccentric vs. stretch-shorten cycle), shortening velocity or external load. These concepts should thus be foci of future research.

\section{Length-tension effects}

The lack of change in tendon stiffness after short- and moderate-duration stretching implies that the muscle should function at the same length for a given level of muscle force after stretching; thus shifts in the force-length (length-tension) relation might not be expected to underpin force losses. Nonetheless, several studies have confirmed that the active length-tension relationship is shifted towards longer lengths (i.e. larger joint angles; rightward shift) after SS (Cramer et al. 2007; Takeuchi and Nakamura 2020; Weir et al. 2005). This is important as many studies test the impact of SS during contractions (often isometric) at relatively short muscle lengths; in fact, all studies on the human plantar flexors are likely to have tested on the ascending limb of the force-length relation, and thus at a 'short' muscle length (Herzog et al. 1991; Maganaris 2003). Therefore, the results of many studies would be vulnerable to a rightward shift that would manifest as a reduced maximal force. In fact, studies in which tests were conducted at several muscle lengths reported post-stretch strength losses at short muscle lengths but moderate improvements at the longest muscle lengths tested (Balle et al. 2015; Herda et al. 2008; McHugh and Nesse 2008; McHugh et al. 2013; Nelson et al. 2001a). Collectively, these data support a 
rightward shift in the length-tension relation and suggest that at least some of the force loss measured in previous studies might be explained by this mechanism. Future studies might circumvent this issue by testing muscle function at several muscle lengths or reporting muscle length-specific forces (or angle-specific joint torques) during dynamic muscle contractions.

The question also arises as to the mechanism underpinning the shift in the force-length relation, given that reductions in tendon stiffness, which would tend to reduce the muscle length for a given force level, are uncommon after short- and moderate-duration stretching. One possibility is that PICs (described above) are more affected at some joint angles, and thus muscle lengths, than others, altering muscle activation in a muscle length-dependent manner. PICs are known to be joint angle dependent, partly because altering the length of the antagonist muscle influences reciprocal inhibition onto the agonist muscle (Gorassini et al. 2002) and partly because the influence of PIC function on agonist force production is muscle length dependent (Kim 2017). Therefore, PICs in agonist muscles should be stronger at longer muscle lengths, and thus potentially less susceptible to post-stretch attenuation. However, this hypothesis is yet to be tested. An additional neural hypothesis is that muscle stretching may reduce inhibitory afferent responses that would otherwise act to reduce neural drive to muscles held at longer lengths. The effect of muscle length on inhibitory gain can be readily observed in H-reflex measurements, whereby a reduction in $\mathrm{H}$-amplitude (i.e. greater inhibition) is observed as agonist muscle length is increased in muscle groups such as the plantar flexors (Blazevich et al. 2012a; Guissard et al. 1988; Mark et al. 1968) inhibitory feedback through reciprocal, cutaneous, recurrent, and presynaptic inhibitory pathways strongly reduces H-reflex amplitudes (Blazevich et al. 2012b; Crone et al. 1990; Day et al. 1984) so a greater reduction in H-amplitude at longer lengths is suggestive of greater inhibition. However, while it is known that acute muscle stretching can 
reduce $\mathrm{H}$-reflex amplitudes, possibly indicating an increase in inhibitory feedback onto the agonist motoneurone pool, the muscle length-dependence of this effect has not been examined to our knowledge. Thus, this hypothesis remains to be properly tested.

Alternatively, length-dependent changes in force production may be triggered by changes in calcium sensitivity of the acto-myosin complex, i.e. a 'fatigue-like' effect. Calcium sensitivity is decreased by factors that reduce the total cross-bridge force for a given amplitude of calcium release (this amplitude is a function of the central, efferent drive to the muscle), including accumulation of metabolic by-products $\left(\mathrm{H}^{+}\right.$ions, inorganic phosphate, adenosine diphosphate, lactate ions and others) or reactive oxygen and nitrogen species (ROS/RNS) as well as increases in muscle temperature (Stephenson and Williams 1985), reductions in intracellular water (Edman and Andersson 1968; Sugi et al. 2013), or dephosphorylation of the myosin regulatory light chain (Vandervoort et al. 1983). Such effects would be consistent with the significant reductions in muscle twitch force usually (Behm et al. 2001; Costa et al. 2010; Opplert et al. 2016), although not always observed after SS (Opplert et al. 2020), given that muscle twitch forces are considered to be highly sensitive to changes in calcium sensitivity (Moore and Stull 1984; Vandenboom et al. 2013). They may also help to explain reductions in electrically-evoked tetanic forces after prolonged stretch (e.g. $5 \mathrm{~min}$ )(Trajano et al. 2014a). It is interesting to consider that the ongoing metabolism of muscle during the ischaemic period of the muscle stretch may trigger the accumulation of metabolic by-products or reactive oxygen or nitrogen species and thus contribute to a loss of calcium sensitivity and a stretch-induced force loss. If stretching were to negatively affect contractile dynamics through a reduction in calcium sensitivity then these effects could be (at least partly) overcome by moving the agonist muscle to a longer length, which increases calcium sensitivity (Balnave and Allen 1996; Stephenson and 
Wendt 1984), and this might partly explain the length-dependence of post-SS force loss. The effects of stretching are not well understood in this context, although it is known that passive muscle stretching can increase ROS/RNS production in skeletal muscle, either as a direct effect of the stretch (Chambers et al. 2009; Palomero et al. 2012; Tidball et al. 1998) or through reduction in muscle circumference during stretch. This increases intra-muscular pressure to expel blood from, and prevents arterial (oxygenated) flow into, the muscle (Otsuki et al. 2011). An increase in ROS/RNS production can reduce calcium release from the sarcoplasmic reticulum, impairing excitation-contraction coupling and consequently reducing muscle force (Bruton et al. 2008; Lamb and Westerblad 2011). In humans, Trajano et al. (2014b) found that continuous plantar flexors stretch ( 1 set of $5 \mathrm{~min}$ ) produced greater ischemia, estimated using near infra-red spectroscopy, than intermittent stretching ( 5 sets of 1 min; 15 -s interval), however the multiple cycles of ischemia and reperfusion during intermittent stretching might be expected to cause greater ROS production (Blaisdell 2002; Gute et al. 1998; Powers and Jackson 2008). The greater magnitude and longer duration (at least $30 \mathrm{~min}$ ) of force loss after intermittent SS observed by the researchers is consistent with this hypothesis, however no evidence of impairment of the excitation-contraction coupling process was detected during electricallystimulated contractions, so other mechanisms must have impacted muscle function. Therefore, although it is possible that an increased production of ROS/RNS or other metabolic products is involved in the force loss observed after (particularly intermittent) stretching, there is currently a lack of direct evidence in humans.

\section{Architecture and gearing effects}


Alterations in muscle blood flow, pressures or connective tissue (intramuscular or tendinous) properties might theoretically influence the muscle's architectural organisation, and particularly fibre (pennation) angle. Increases in pre-contraction fascicle angle may reduce the proportion of fibre force directed along the tendon and thus total muscle force. Also, any change in the rotation of fibres (and thus the gear ratio adopted) during contraction may influence the force (and power)-velocity profile of a muscle (Eng et al. 2018). However, studies employing the requisite imaging technologies have reported no change in resting pennation angle or fascicle length following SS (Ce et al. 2015; Kay and Blazevich 2009a;b; Opplert et al. 2016), despite reductions in force and stiffness. Furthermore, where a reduction in whole-muscle operating length has been reported (Kubo et al. 2001) after longer SS durations (10 min), no reduction in maximal voluntary force was observed. Finally, no studies have examined fascicle rotation (i.e. gearing) during contractions before and after stretching, so it is not yet known whether stretching alters dynamic fibre or fascicle behaviour. Therefore, there is no current evidence that SSinduced alterations in muscle architecture directly influence muscle force production. However, dynamic fascicle behaviour has not been examined, so it is unclear whether fascicle rotation during contraction is altered by acute muscle stretching.

\section{Titin}

Passive muscle stiffness has been suggested to be largely attributable to adaptations in collagenous components embedded within the extracellular matrix (ECM) of endo-, peri-, and epimysial connective tissues (Ward et al. 2020), with titin filaments acting as a molecular spring responsible for almost all passive force within the myofibril (Herzog et al. 2012). However, more recent work in animal models has suggested that titin may still play an important role in 
determining stiffness at the whole muscle level (Brynnel et al. 2018), thus potential SSdependent changes in titin mechanics may theoretically affect its contribution to whole muscle stiffness and force production. The elimination of titin from the myofibrils has been demonstrated to abolish all passive and active force in myofibrils, indicating the importance of titin not only for passive force production but also for active force transmission within the sarcomere (Leonard and Herzog 2010). More recently, direct force production by titin has been shown through folding of its Ig domains (Rivas-Pardo et al. 2016). Titin can also contribute to active force during eccentric contractions through calcium binding to titin (to increase titin's inherent stiffness) and by titin binding to the actin filament, thereby reducing titin's free spring length to increase its stiffness and force contribution (Rassier et al. 2015)). Importantly, titin's stiffness, and therefore its contribution to force at a given sarcomere length, is thought to be influenced by muscle length during contraction initiation or by passive stretch (Herzog 2014; Leonard and Herzog 2010). When contractions are initiated at shorter muscle lengths, titin is thought to bind on the actin filament further from the z-line, which would decrease the length of the free part of the titin filament (Herzog et al. 2012) and increase titin's stiffness. However, during passive stretch titin fails to bind to actin increasing its spring length and decreasing its stiffness. Furthermore, as no contraction is initiated during passive stretch, calcium is disassociated from titin further reducing its inherent stiffness. While changes in titin stiffness could theoretically contribute to the temporary post-stretch reduction in muscle stiffness, increased slack length, rightward shift in the length-tension curve, and maximal force reduction, the effects could possibly be very short lasting - altered titin stiffness may persist for only a few seconds after stretch or contraction is terminated (Lee et al. 2007). Thus, there is no current evidence that longer-term changes in titin properties (i.e. minutes after stretch) might produce an 
ongoing effect on muscle force. Further research is required to fully elucidate whether a titinbased mechanism contributes to post-SS force losses.

\section{Summary of morphological mechanisms}

As summarised in Table 3, reductions in MTU stiffness and maximal force output are commonly reported following longer duration stretches, with force reductions primarily occurring at shorter muscle lengths with no change or slight increases at the longest muscle lengths. However, changes in MTU stiffness are not temporally associated with change in muscle force production and are therefore unlikely to directly influence force. It is also unlikely that changes in tendon stiffness (which might then reduce active muscle length) are sufficient to affect muscle force. Nonetheless, alterations in passive muscle force, possibly indicating a reduction in stiffness of the muscle's parallel elastic components, is commonly observed. Theoretically, changes in the PEC may influence muscle force by (i) impairing force transmission at several levels of the muscle's hierarchy, (ii) reducing the radial (transverse) component of passive fibre forces that is axial (longitudinal) to the line of action of the muscle, and (iii) reducing fibre/fascicle rotation during contraction (including in fixed-end isometric contractions, during which tendon stretch allows for muscle shortening) and thus altering both the muscle's gear ratio and line of pull of fibres. However, these possibilities have yet to be explicitly studied in relation to the post-SS force loss. Notably, SS tends to promote a rightward shift in the force length curve; factors that might underpin the shift, including reduction of PIC strength (which is joint angle-dependent), length-dependent inhibition of the motoneurone pool, and reduced $\mathrm{Ca}^{2+}$ sensitivity (e.g. through metabolite accumulation) could all impact muscle force production but have also received little attention to date. Finally, changes in the properties 
of titin may speculatively influence muscle force, however this possibility has yet to be studied. Importantly, the current literature reveals that some mechanisms often theorised to underpin post-SS reductions in force are often not detected, poorly related to changes in force, or somewhat speculative and remain to be examined.

\section{PLACE TABLE 3 APPROXIMATELY HERE}

\section{Psychological Influences}

\section{Mental energy deficit}

Prolonged SS at or near the point of discomfort can be uncomfortable and it may require concentration (cognitive demand) for maintenance of joint position and stretch intensity. If this triggers some level of mental fatigue then this might have some impact on performance, especially in repetitive or prolonged, continuous activities (Marcora et al. 2009; Pageaux et al. 2013; 2014). Mentally fatiguing tasks cause individuals to perceive a subsequent task to be more taxing or demanding, and thus they may cease the activity earlier or provide less effort (Marcora et al. 2009; Pageaux et al. 2013; 2014). This mental energy deficit is a global body phenomenon as performance impairments have been demonstrated in non-exercised homologous and heterologous muscles following fatiguing protocols of a contralateral muscle that necessitated prolonged concentration to maintain the fatigue-inducing forces (Halperin et al. 2015). Furthermore, the stretching of one muscle group can enhance the ROM of other homologous (Chaouachi et al. 2017) and heterologous (Behm et al. 2016b) muscle groups. This global effect of SS may speculatively be attributed to the concept of increased stretch tolerance (Magnusson et al. 1996b; 1997). The outcomes of studies on the effects of unilateral SS on contralateral limb performance are 
conflicting, with impairments in knee extensor MVC force (4.2\%)(Caldwell et al. 2019), rate of force development (10.8\%)(Jelmini et al. 2018), voluntary activation (interpolated twitch technique: $7 \%)$ and mechanomyogram $(9 \%)(\mathrm{Ce}$ et al. 2020) contrasting with no contralateral decrements in knee extension MVC (Behm et al. 2019) or isokinetic torque or power (Chaouachi et al. 2017). Hence if a psycho-physiological phenomenon such as stretch tolerance can induce global increases in ROM, with further evidence, albeit not unanimous for SS-induced contralateral strength and activation deficits, it is likely that a prior mentally fatiguing task such as prolonged SS at or near the point of discomfort could contribute to global performance impairments. As the literature is not extensive concerning non-local stretching effects, more research is needed.

\section{Placebo and Nocebo effects}

The review by Behm et al. (2016a) highlighted a number of limitations within current research, one being the possibility of placebo or nocebo effects that could influence the performance of participants who were familiar with the literature relating to the effects of SS. In that context, Janes et al. (2016) demonstrated that participants who were deceived to believe that prolonged SS was beneficial showed increases in knee extension MVC force (5.1\%-8.8\%). Similarly, Bertolaccini et al. (2019) used positive and negative biased groups as well as a control group. There were no differences in total number of repetitions performed during a strength endurance test ( 4 sets to failure at $70 \%$ of 1 repetition maximum (1RM)), but the positively biased group performed a greater number of repetitions in the final set. Blazevich and colleagues (2018) incorporated $30 \mathrm{~s}$ of SS into a full warm-up and found improved ROM but no deficits in jumping, sprinting or agility tests. Participants were queried about their performance expectations when stretching was included. Prior to the experiment, 18/20 participants indicated 
that dynamic stretching was most likely to improve performance and 15/20 participants nominated no stretching to be least likely. However, there was no relation between their ratings and test performances. Nevertheless, the authors reported evidence that including SS or dynamic stretching into the warm-up instilled more confidence in their subsequent athletic performance. Hence, the body of literature on placebo or nocebo effects of stretch perceptions is sparse. But since psychological effects play a vital role for optimal performance, and appropriate durations of SS and dynamic stretching within a full warm-up generally do not impair performance, short to moderate durations of SS (e.g. $<60 \mathrm{~s}$ ) within a comprehensive warm-up can be generally recommended.

\section{PLACE TABLE 4 APPROXIMATELY HERE}

\section{Conclusions}

Various forms of stretching have been used for millennia in preparation for subsequent activity (acute), training to enhance ROM (chronic), rehabilitation, psycho-physiological relaxation (i.e. yoga), and other scenarios. Evidence has accumulated over approximately the last 25 years for SS-induced impairments with prolonged acute stretching when performed without a complement of dynamic warm-up activities or with little time between the end of muscle stretching and commencement of physical activity. Mechanisms underlying acute performance impairments under these conditions have been attributed to neural, morphological and psychological factors. While SS-induced EMG decrements are inconsistently reported in the stretch literature, EMG normalised to the M-wave provides more consistent evidence for neural deficits. Reflex inhibition (i.e. H-reflex, E-reflex, GTO) from SS tends to dissipate quickly after 
SS. The literature illustrates minimal effects of SS on corticospinal excitability or the cortical silent period, but motoneurone excitability can be adversely affected by stretch-induced alterations in the strength of persistent inward currents (PICs), which may persist up to $10 \mathrm{~min}$ after stretching; both the temporal profile of PIC changes and their importance for achieving maximal muscle activation implicate this mechanism as a probable primary driver of SS-induced force losses. Regarding possible morphological effects, shifts in the active force-length relationship appear to be associated with force changes. They may impact directly, as a result of increasing (at longer lengths) or decreasing (at shorter lengths) the maximal force production capacity. However, the shift may also implicate other mechanisms, such as reductions in PIC strength (which are joint angle-dependent), inhibitory feedback onto the motoneurone pool, or $\mathrm{Ca}^{2+}$ sensitivity (associated with metabolite accumulation; i.e. 'fatigue-like effects) as possible mechanisms influencing muscle force production. Nonetheless, direct examination of these possibilities is needed before conclusions can be made as to their direct importance. Alterations in PEC stiffness may also be evoked by SS, and while there is not expected to be a direct impact on muscle force (since the PEC is largely unloaded during contraction), indirect effects on force transmission efficiency, decreased off-axis passive force contributions or alterations in fibre rotation during contraction (i.e. 'gearing'; including during fixed-end isometric contractions) may influence force production. Again, however, little direct evidence of these mechanisms is available. Also, while effects of SS on titin function/properties are speculatively possible, no current evidence exists to determine possible effects. Finally, psychological factors such as the mental energy deficit arising from prior prolonged focus or concentration with stretching or nocebo effects could also contribute to adverse performance outcomes following SS (Figure 1).

\section{PLACE FIGURE 1 APPROXIMATELY HERE}




\section{Recommendations}

Whilst appropriate durations of SS ( $<60 \mathrm{~s}$ per muscle group) within a full dynamic warmup can improve ROM with trivial (positive or negative) performance effects, there may be other benefits. SS may be used, if an individual wishes, before physical activities as long as SS durations are moderate (e.g. $<1$ min per muscle group), especially when performed as part of a complete, pre-exercise routine. It may also assist force production at long muscle lengths when performed immediately prior to a task. With regards to psychological benefits, short duration pre-exercise stretching may also provide an opportunity for team bonding (stretch as a group). SS can also work as a form of self-diagnosis; a way to check different regions of the body for unusual soreness or tightness either before or after training and competitions. Additionally, reflex-induced reductions in sympathetic drive can contribute to overall health and performance by decreasing muscle tone, heart rate and blood pressure (van den Berg and Cabri 1999; Wu et al. 1999), which may speculatively improve performance in accuracy sports such as shooting, archery and biathlon. If longer-duration stretches are necessary within a warm-up to achieve substantial ROM improvements in sports or activities that require it then some performance decrement may be expected if minimal time elapses between stretching and task performance (at least in tasks performed at short and moderate muscle lengths). In these cases mitigation strategies would be useful, however there is still a lack of understanding of the mechanisms underlying SS-induced force reductions, so it is not yet possible to describe an optimal suite of strategies for use. Further research is required, in line with the recommendations of the present review, in order to better understand the mechanisms impacting muscle force reduction after SS. 


\section{Acknowledgement}

The authors would like to acknowledge Dr. Shahab Alizadeh for his contributions to the composition of the figure.

\section{Table Legends}

Table 1: Sample of acute static stretching studies since 2016 that have investigated strength and power performance variables.

Acronyms: BB: basketball, CMJ: countermovement jump, Hams: hamstrings, HF: hip flexion, KE: knee extension, KF: knee flexion, MVC: maximum voluntary contraction, NR: not reported, NS: non-significant, POD: point of discomfort, RA: recreationally active, RT: resistance trained, RTime: reaction time, PT: peak torque, Quads: quadriceps, Sed: sedentary. Shaded boxes highlight studies that recruited youth.

Table 2. Summary of evidence for/against the effects of neurological factors on the SS-induced force loss.

Table 3. Summary of evidence for/against the effects of morphological factors on the SSinduced force loss.

Table 4: Summary of evidence for/against the effects of psychological factors on the SS-induced force loss.

\section{Figure Legend}

Figure 1: A) The effects of static stretching (SS) with and without a warm-up on performance. B) Mechanisms potentially underpinning the SS-induced performance impairment.

\section{References}

Avela J, KyrîlÑinen H, Komi PV (1999) Altered reflex sensitivity after repeated and prolonged passive muscle stretching. J Appl Physiol 86:1283-1291.

Avloniti A et al. (2016a) The acute effects of static stretching on speed and agility performance depend on stretch duration and conditioning level. J Strength Cond Res 30:2767-2773. doi: $10.1519 /$ JSC. 0000000000000568

Avloniti A et al. (2016b) The effects of static stretching on speed and agility: One or multiple repetition protocols? Eur J Sport Sci 16:402-408. doi:10.1080/17461391.2015.1028467

Babault N, Kouassi BY, Desbrosses K (2010) Acute effects of 15min static or contract-relax stretching modalities on plantar flexors neuromuscular properties. J Sci Med Sport 13:247-252. doi:10.1016/j.jsams.2008.12.633

Balci LAA, H.K.; Alkan, M.; (2019) Effects of 30 second versus 45 second static stretching on vertical jump performance. Gazzetta Medica Italiana 178:112-117. 
Balle SS, Magnusson SP, McHugh MP (2015) Effects of contract-relax vs static stretching on stretch-induced strength loss and length-tension relationship. Scand J Med Sci Sports 25:764-769. doi:10.1111/sms.12399

Balnave CD, Allen DG (1996) The effect of muscle length on intracellular calcium and force in single fibres from mouse skeletal muscle. J Physiol 492 ( Pt 3):705-713. doi:10.1113/jphysiol.1996.sp021339

Barbosa GMD, Pinheiro SM, Pereira Rego JT, Oliveira TLC, Ferreira Silva KK, Silva Dantas PM, Brito Vieira WH (2019) Acute effects of stretching and/or warm-up on neuromuscular performance of volleyball athletes: a randomized cross-over clinical trial. Sports Sci Health doi:https://doi.org/10.1007/s11332-019-00576-8

Baskin RJ, Paolini PJ (1967) Volume change and pressure development in muscle during contraction. Am J Physiol 213:1025-1030. doi:10.1152/ajplegacy.1967.213.4.1025

Behm DG (2018) The Science and Physiology of Flexibility and Stretching: Implications and Applications in Sport Performance and Health. Routledge Publishers, London, UK. Chapter 4: 48-96.

Behm DG, Bambury A, Cahill F, Power K (2004) Effect of acute static stretching on force, balance, reaction time, and movement time. Med Sci Sports Exerc 36:1397-1402.

Behm DG, Blazevich AJ, Kay AD, McHugh M (2016a) Acute effects of muscle stretching on physical performance, range of motion, and injury incidence in healthy active individuals: a systematic review. Appl Physiol Nutr Metab 41:1-11. doi:10.1139/apnm2015-0235

Behm DG, Button DC, Butt JC (2001) Factors affecting force loss with prolonged stretching. Can J Appl Physiol 26:261-272.

Behm DG, Cavanaugh T, Quigley P, Reid JC, Nardi PS, Marchetti PH (2016b) Acute bouts of upper and lower body static and dynamic stretching increase non-local joint range of motion. Eur J Appl Physiol 116:241-249. doi:10.1007/s00421-015-3270-1

Behm DG, Chaouachi A (2011) A review of the acute effects of static and dynamic stretching on performance. Eur J Appl Physiol 111:2633-2651 doi:10.1007/s00421-011-1879-2

Behm DG, St-Pierre DM (1997) The muscle activation-force relationship is unaffected by ischaemic recovery. Can J Appl Physiol 22:468-478.

Behm DG, Lau, R.J., O’Leary, J.J., Rayner, M.C.P., Burton, E.A., Lavers, L. (2019) Acute effects of unilateral self-administered static stretching on contralateral limb performance. J Performance Health Res 3:1-7. doi:DOI: 10.25036/jphr.2019.3.1.behm

Bertolaccini AL, da Silva AA, Teixeira EL, Schoenfeld BJ, de Salles Painelli V (2019) Does the Expectancy on the Static Stretching Effect Interfere With Strength-Endurance Performance? J Strength Cond Res doi:10.1519/JSC.0000000000003168

Binder MD, Powers RK, Heckman C (2020) Nonlinear input-output functions of motoneurons. J Physiol 35:31-39.

Blackburn JT, Padua DA, Riemann BL, Guskiewicz KM (2004) The relationships between active extensibility, and passive and active stiffness of the knee flexors. J Electromyogr Kinesiol 14:683-691. doi:10.1016/j.jelekin.2004.04.001

Blaisdell FW (2002) The pathophysiology of skeletal muscle ischemia and the reperfusion syndrome: a review. Cardiovasc Surg 10:620-630. doi:10.1016/s0967-2109(02)00070-4

Blazevich AJ, Cannavan D, Waugh CM, Fath F, Miller SC, Kay AD (2012a) Neuromuscular factors influencing the maximum stretch limit of the human plantar flexors. J Appl Physiol 113:1446-1455. doi:10.1152/japplphysiol.00882.2012 
Blazevich AJ et al. (2018) No effect of muscle stretching within a full, dynamic warm-up on athletic performance. Med Sci Sports Exerc 50:1258-1266.

doi:10.1249/MSS.0000000000001539

Blazevich AJ, Kay AD, Waugh C, Fath F, Miller S, Cannavan D (2012b) Plantar flexor stretch training increases reciprocal inhibition measured during voluntary dorsiflexion. $\mathrm{J}$ Neurophysiol 107:250-256. doi:10.1152/jn.00407.2011

Bojsen-Moller J, Magnusson SP, Rasmussen LR, Kjaer M, Aagaard P (2005) Muscle performance during maximal isometric and dynamic contractions is influenced by the stiffness of the tendinous structures. J Appl Physiol (1985) 99:986-994. doi:10.1152/japplphysiol.01305.2004

Borg TK, Caulfield JB (1980) Morphology of connective tissue in skeletal muscle. Tissue Cell 12:197-207. doi:10.1016/0040-8166(80)90061-0

Bouvier T, Opplert J, Cometti C, Babault N (2017) Acute effects of static stretching on muscletendon mechanics of quadriceps and plantar flexor muscles. Eur J Appl Physiol 117:1309-1315. doi:10.1007/s00421-017-3618-9

Brusco CM, Pompermayer MG, Esnaola BW, Lima CS, Pinto RS (2018) Short duration static stretching preceded by cycling warm-up reduces vertical jump performance in healthy males. Sport Sci Health 14:77-82. doi:https://doi.org/10.1007/s11332-017-0404-3

Bruton JD et al. (2008) Reactive oxygen species and fatigue-induced prolonged low-frequency force depression in skeletal muscle fibres of rats, mice and SOD2 overexpressing mice. J Physiol 586:175-184. doi:10.1113/jphysiol.2007.147470

Brynnel A et al. (2018) Downsizing the molecular spring of the giant protein titin reveals that skeletal muscle titin determines passive stiffness and drives longitudinal hypertrophy. Elife 7: 121-134. doi:10.7554/eLife.40532

Budini F, Christova M, Gallasch E, Kressnik P, Rafolt D, Tilp M (2018a) Transient increase in cortical excitability following static stretching of plantar flexor muscles. Front Physiol 9:530. doi:10.3389/fphys.2018.00530

Budini F, Christova M, Gallasch E, Rafolt D, Tilp M (2018b) Soleus H-Reflex inhibition decreases during $30 \mathrm{~s}$ static stretching of plantar flexors, showing two recovery steps. Front Physiol 9:935. doi:10.3389/fphys.2018.00935

Budini F, Gallasch E, Christova M, Rafolt D, Rauscher AB, Tilp M (2017) One minute static stretch of plantar flexors transiently increases $\mathrm{H}$ reflex excitability and exerts no effect on corticospinal pathways. Exper Physiol 102:901-910.

Budini F, Kemper D, Christova M, Gallasch E, Rafolt D, Tilp M (2019) Five minutes static stretching influences neural responses at spinal level in the background of unchanged corticospinal excitability. J Musculoskel Neuronal Interactions 19:30-42.

Caldwell SL, Bilodeau RLS, Cox MJ, Peddle D, Cavanaugh T, Young JD, Behm DG (2019) Unilateral hamstrings static stretching can impair the affected and contralateral knee extension force but improve unilateral drop jump height. Eur J Appl Physiol 119:19431949. doi:10.1007/s00421-019-04182-X

Canedo A (1997) Primary motor cortex influences on the descending and ascending systems. Progress Neurobiol 51:287-335.

Ce E et al. (2020) Neuromuscular versus mechanical stretch-induced changes in contra- versus ipsilateral muscle. Med Sci Sports Exerc doi:10.1249/MSS.0000000000002255

Ce E, Longo S, Rampichini S, Devoto M, Limonta E, Venturelli M, Esposito F (2015) Stretchinduced changes in tension generation process and stiffness are not accompanied by 
alterations in muscle architecture of the middle and distal portions of the two gastrocnemii. J Electromyogr Kinesiol 25:469-478. doi:10.1016/j.jelekin.2015.03.001

Celebi MM, Kudas S, Zergeroglu AM (2016) Effects of static stretching on quadriceps peak torque and hip range of motion in professional soccer players and sedentary subjects. Dahili Bilimleri Medical Sci 69:187-191. doi:10.1501/Tipfak_000000942

Chaabene H, Behm DG, Negra Y, Granacher U (2019) Acute effects of static stretching on muscle strength and power: An attempt to clarify previous caveats. Front Physiol 10:1468. doi:10.3389/fphys.2019.01468

Chambers MA, Moylan JS, Smith JD, Goodyear LJ, Reid MB (2009) Stretch-stimulated glucose uptake in skeletal muscle is mediated by reactive oxygen species and p38 MAP-kinase. $\mathrm{J}$ Physiol 587:3363-3373. doi:10.1113/jphysiol.2008.165639

Chaouachi A, Padulo J, Kasmi S, Othmen AB, Chatra M, Behm DG (2017) Unilateral static and dynamic hamstrings stretching increases contralateral hip flexion range of motion. Clin Physiol Funct Imaging 37:23-29. doi:10.1111/cpf.12263

Chatzopoulos D, Doganis G, Lykesas G, Koutlianos N, Galazoulas C, Bassa E (2019) Effects of static and dynamic stretching on force sense, dynamic flexibility and reaction time of children. The Open Sports Sci J 12:22-27. doi:10.2174/1875399X01912010022

Cleland CL, Hayward L, Rymer WZ (1990) Neural mechanisms underlying the clasp-knife reflex in the cat. II. Stretch-sensitive muscular-free nerve endings. J Neurophysiol 64:1319-1330. doi:10.1152/jn.1990.64.4.1319

Cleland CL, Rymer WZ (1990) Neural mechanisms underlying the clasp-knife reflex in the cat. I. Characteristics of the reflex J Neurophysiol 64:1303-1318. doi:10.1152/jn.1990.64.4.1303

Cleland CL, Rymer WZ (1993) Functional properties of spinal interneurons activated by muscular free nerve endings and their potential contributions to the clasp-knife reflex. J Neurophysiol 69:1181-1191. doi:10.1152/jn.1993.69.4.1181

Costa PB, Ryan ED, Herda TJ, Walter AA, Hoge KM, Cramer JT (2010) Acute effects of passive stretching on the electromechanical delay and evoked twitch properties. Eur J Appl Physiol 108:301-310.

Cramer JT et al. (2007) Acute effects of static stretching on characteristics of the isokinetic angle - torque relationship, surface electromyography, and mechanomyography. J Sports Sci 25:687-698.

Crone C, Hultborn H, Mazieres L, Morin C, Nielsen J, Pierrot-Deseilligny E (1990) Sensitivity of monosynaptic test reflexes to facilitation and inhibition as a function of the test reflex size: a study in man and the cat. Exp Brain Res 81:35-45. doi:10.1007/BF00230098

Cui, J., Blaha, C., Moradkhan, R., Gray, K.S., and Sinoway, L.I. (2006) Muscle sympathetic nerve activity responses to dynamic passive muscle stretch in humans. J Physiol 576(2): 625-634. Available from PM:16873399.

Damasceno MV, Duarte M, Pasqua LA, Lima-Silva AE, MacIntosh BR, Bertuzzi R (2014) Static stretching alters neuromuscular function and pacing strategy, but not performance during a 3-km running time-trial. PLoS One 9:e99238. doi:10.1371/journal.pone.0099238

Day BL, Marsden CD, Obeso JA, Rothwell JC (1984) Reciprocal inhibition between the muscles of the human forearm. J Physiol 349:519-534. doi:10.1113/jphysiol.1984.sp015171

de Souza RF, deMatos DG, Costa Nogueira A, Pires Ferreira AR, Freitas Zanona A, Aidar, FJ (2019) Analysis of muscle recovery time after acute stretching at peak torque of the 
hamstring muscles. Medicina dello Sport 72:112-118. doi:10.23736/S00257826.19.03136-3)

Decoster LC, Cleland J, Altieri C, Russell P (2005) The effects of hamstring stretching on range of motion: a systematic literature review. J Orthop Sports Phys Ther 35:377-387. doi:10.2519/jospt.2005.35.6.377

Delwaide PJ, Toulouse P, Crenna P (1981) Hypothetical role of long-loop reflex pathways. Appl Neurophysiol 44:171-176.

Dimitrova NA, Dimitrov GV (2003) Interpretation of EMG changes with fatigue: facts, pitfalls, and fallacies. J Electromy Kinesiol 13:13-36.

Draeger D, Smith J (1969) Comprehensive Asian Fighting Arts. Chapter 5: pp: 63-102.

Edin BB, Vallbo AB (1990) Classification of human muscle stretch receptor afferents: a Bayesian approach. J Neurophysiol 63:1314-1322.

Edman KA, Andersson KE (1968) The variation in active tension with sarcomere length in vertebrate skeletal muscle and its relation to fibre width. Experientia 24:134-136. doi:10.1007/BF02146942

Eng CM, Azizi E, Roberts TJ (2018) Structural determinants of muscle gearing during dynamic contractions. Integr Comp Biol 58:207-218. doi:10.1093/icb/icy054

Eng CM, Roberts TJ (2018) Aponeurosis influences the relationship between muscle gearing and force. J Appl Physiol (1985) 125:513-519. doi:10.1152/japplphysiol.00151.2018

Esposito F, Limonta E, Ce E (2011) Passive stretching effects on electromechanical delay and time course of recovery in human skeletal muscle: new insights from an electromyographic and mechanomyographic combined approach. Eur J Appl Physiol 111:485-495. doi:10.1007/s00421-010-1659-4

Farina D, Fosci M, Merletti R (2002) Motor unit recruitment strategies investigated by surface EMG variables. J Appl Physiol 92:235-247.

Fjerstad BM, Hammer RL, Hammer AM, Connolly G, Lomond KV, O'Connor P (2018) Comparison of two static stretching procedures on hip adductor flexibility and strength. Int J Exerc Sci 11:1074-1085.

Fowles JR, Sale DG, MacDougall JD (2000) Reduced strength after passive stretch of the human plantar flexors. J Appl Physiol 89:1179-1188.

Freitas SR, Vaz JR, Bruno PM, Andrade R, Mil-Homens P (2016) Stretching effects: Highintensity \& moderate-duration vs. low-intensity \& long-duration. Int J Sports Med 37:239-244. doi:10.1055/s-0035-1548946

Frigon A, Carroll TJ, Jones KE, Zehr EP, Collins DF (2007) Ankle position and voluntary contraction alter maximal $\mathrm{M}$ waves in soleus and tibialis anterior. Muscle Nerve 35(6): 756-766.

Gillies AR, Lieber RL (2011) Structure and function of the skeletal muscle extracellular matrix. Muscle Nerve 44:318-331. doi:10.1002/mus.22094

Godges JJ, MacRae H, Longdon C, Tinberg C (1989) The effects of two stretching procedures on the economy of walking and jogging. J Orthopaed Sport Physical Ther 7:350-357.

Gorassini M, Yang JF, Siu M, Bennet DJ (2002) Intrinsic activation of human motoneurons: possible contribution to motor unit excitation. J Neurophysiol 87:1850-1858.

Guissard N, Duchateau J (2006) Neural aspects of muscle stretching. Exerc Sport Sci Rev 34:154-158.

Guissard N, Duchateau J, Hainaut K (1988) Muscle stretching and motoneuron excitability. Eur J Appl Physiol 58:47-52. 
Guissard N, Duchateau J, Hainaut K (2001) Mechanisms of decreased motoneurone excitation during passive muscle stretching. Exper Brain Res 137:163-169.

Gute DC, Ishida T, Yarimizu K, Korthuis RJ (1998) Inflammatory responses to ischemia and reperfusion in skeletal muscle. Mol Cell Biochem 179:169-187. doi:10.1023/a:1006832207864

Hagg GM (1992) Interpretation of EMG spectral alterations and alteration indexes at sustained contraction. J Appl Physiol (1985) 73:1211-1217. doi:10.1152/jappl.1992.73.4.1211

Halperin I, Chapman DW, Behm DG (2015) Non-local muscle fatigue: effects and possible mechanisms. Eur J Appl Physiol 115:2031-2048. doi:10.1007/s00421-015-3249-y

Hatano $\mathrm{G}$ et al. (2019) Hamstring stiffness returns more rapidly after static stretching than range of motion, stretch tolerance, and isometric peak torque. J Sport Rehabil 28:325-331. doi:10.1123/jsr.2017-0203

Heckman C (1994) Computer simulations of the effects of different synaptic input systems on the steady-state input-output structure of the motoneuron pool. J Neurophysiol 71:17271739.

Heiderscheit BC, Sherry MA, Silder A, Chumanov ES, Thelen DG (2010) Hamstring strain injuries: recommendations for diagnosis, rehabilitation, and injury prevention. J Orthop Sports Phys Ther 40:67-81. doi:10.2519/jospt.2010.3047

Herda TJ, Cramer JT, Ryan ED, McHugh MP, Stout JR (2008) Acute effects of static versus dynamic stretching on isometric peak torque, electromyography, and mechanomyography of the biceps femoris muscle. J Strength Cond Res 22:809-817.

Herzog W (2014) The role of titin in eccentric muscle contraction. J Exp Biol 217:2825-2833. doi:10.1242/jeb.099127

Herzog W, Duvall M, Leonard TR (2012) Molecular mechanisms of muscle force regulation: a role for titin? Exerc Sport Sci Rev 40:50-57. doi:10.1097/JES.0b013e31823cd75b

Herzog W, Read LJ, Ter Keurs HE (1991) Experimental determination of force-length relations of intact human gastrocnemius muscles. Clin Biomech 6:230-238. doi:10.1016/02680033(91)90051-Q

Hirata K, Miyamoto-Mikami E, Kanehisa H, Miyamoto N (2016) Muscle-specific acute changes in passive stiffness of human triceps surae after stretching. Eur J Appl Physiol 116:911918. doi:10.1007/s00421-016-3349-3

Holt NC, Danos N, Roberts TJ, Azizi E (2016) Stuck in gear: age-related loss of variable gearing in skeletal muscle. J Exp Biol 219:998-1003. doi:10.1242/jeb.133009

Houk JC, Crago PE, Rymer WZ (1980) Functional properties of the Golgi tendon organs. In: Desmedt JE (ed) Spinal and Supraspinal Mechanisms of Voluntary Motor Control and Locomotion, Vol 8. pp 33-43.

Huijing P (1999) Muscular force transmission: a unified, dual or multiple system? A review and some explorative experimental results. Arch Physiol Biochem 107:292-311. doi:10.1076/13813455199908107041QFT292

Huijing PA, Baan GC (2003) Myofascial force transmission: muscle relative position and length determine agonist and synergist muscle force. J Appl Physiol (1985) 94:1092-1107. doi:10.1152/japplphysiol.00173.2002

Huijing PA, van de Langenberg RW, Meesters JJ, Baan GC (2007) Extramuscular myofascial force transmission also occurs between synergistic muscles and antagonistic muscles. J Electromyogr Kinesiol 17:680-689. doi:10.1016/j.jelekin.2007.02.005 
Hunter DG, Spriggs J (2000) Investigation into the relationship between the passive flexibility and active stiffness of the ankle plantar-flexor muscles. Clin Biomech 15:600-606. doi:10.1016/s0268-0033(00)00017-6

Hunter DG, Coveney V, Spriggs J (2001) Investigation into the effect of static stretching on the active stiffness and damping characteristics of the ankle joint plantar flexors. Physical Therapy in Sport 2:15-22.

Ikeda N, Inami T, Kawakami Y (2019) Stretching combined with repetitive small length changes of the plantar flexors enhances their passive extensibility while not compromising strength. J Sports Sci Med 18:58-64.

Janes WC, Snow BB, Watkins CE, Noseworthy EA, Reid JC, Behm DG (2016) Effect of participants' static stretching knowledge or deception on the responses to prolonged stretching. Appl Physiol Nutr Metab 41:1052-1056. doi:10.1139/apnm-2016-0241

Jaquet D, Mazure AB, Armand S, Charbonnier C, Ziltener JL, Kayser,B (2015) Range of motion and energy cost of locomotion of the late medieval armoured fighter: a proof of concept of confronting the medieval technical literature with modern movement analysis. Historical Methods: J Quantitat Interdisciplin History:1-49.

Jelmini JD, Cornwell A, Khodiguian N, Thayer J, Araujo AJ (2018) Acute effects of unilateral static stretching on handgrip strength of the stretched and non-stretched limb. Eur J Appl Physiol 118:927-936. doi:10.1007/s00421-018-3810-6

Jenner JR, Stephens JA (1982) Cutaneous reflex responses and thier central nervous pathways studied in man. J Physiol 333:405-419.

Judge LW, Avedesian JM, Bellar DM, Hoover DL, Craig BW, Langley J, Nordmann N, Schoeff MA, Dickin C (2020) Pre- and post-activity stretching practices of collegiate soccer coaches in the United States. Intern J Exerc Sci 13:260-272.

Kataura S et al. (2017) Acute effects of the different intensity of static stretching on flexibility and isometric muscle force. J Strength Cond Res 31:3403-3410. doi:10.1519/JSC.0000000000001752

Kato E, Kanehisa H, Fukunaga T, Kawakami Y (2010) Changes in ankle joint stiffness due to stretching: The role of tendon elongation of the gastrocnemius muscle. Eur J Sport Sci 10:111-119. doi:10.1080/17461390903307834

Kay AD, Blazevich AJ (2009a) Isometric contractions reduce plantar flexor moment, Achilles tendon stiffness, and neuromuscular activity but remove the subsequent effects of stretch. J Appl Physiol 107:1181-1189. doi:10.1152/japplphysiol.00281.2009

Kay AD, Blazevich AJ (2009b) Moderate-duration static stretch reduces active and passive plantar flexor moment but not Achilles tendon stiffness or active muscle length. J Appl Physiol 106:1249-1256. doi:10.1152/japplphysiol.91476.2008

Kay AD, Blazevich AJ (2012) Effect of acute static stretch on maximal muscle performance: a systematic review. Med Sci Sports Exerc 44:154-164. doi:10.1249/MSS.0b013e318225cb27

Kay AD, Husbands-Beasley J, Blazevich AJ (2015) Effects of contract-relax, static stretching, and isometric contractions on muscle-tendon mechanics. Med Sci Sports Exerc 47:21812190. doi:10.1249/MSS.0000000000000632

Kay AD, Blazevich, A.J. (2008) Reductions in active plantar flexor moment are significantly correlated with static stretch duration. Eur J Sport Sci 8:41-46.

Kearney RE, Chan CWY (1999) Reflex response of human arm muscles to cutaneous stimulation of the foot. Brain Res 170:214-217. 
Khan SI, Burne JA (2009) Afferents contributing to autogenic inhibition of gastrocnemius following electrical stimulation of its tendon. Brain Res 1282:28-37.

Kim H (2017) Muscle length-dependent contribution of motoneuron Cav1.3 channels to force production in model slow motor unit. J Appl Physiol (1985) 123:88-105. doi:10.1152/japplphysiol.00491.2016

Kokkonen J, Nelson AG, Cornwell A (1998) Acute muscle stretching inhibits maximal strength performance. Res Quart Exerc Sport 69:411-415.

Konrad A, Budini F, Tilp M (2017a) Acute effects of constant torque and constant angle stretching on the muscle and tendon tissue properties. Eur J Appl Physiol 117:1649-1656. doi:10.1007/s00421-017-3654-5

Konrad A, Reiner MM, Thaller S, Tilp M (2019) The time course of muscle-tendon properties and function responses of a five-minute static stretching exercise. Eur J Sport Sci 19:1195-1203. doi:10.1080/17461391.2019.1580319

Konrad A, Stafilidis S, Tilp M (2017b) Effects of acute static, ballistic, and PNF stretching exercise on the muscle and tendon tissue properties. Scand J Med Sci Sports 27:10701080. doi:10.1111/sms. 12725

Konrad A, Tilp M (2020a) The time course of muscle-tendon unit function and structure following three minutes of static stretching. J Sports Sci Med 19:52-58.

Konrad AT, Tilp M.; (2020b) The acute time course of muscle and tendon tissue changes following one minute of static stretching. Current Issues Sport Sci 5:63-78. doi:10.15203/CISS_2020.003

Kruger L (1987) Cutaneous Sensory System. Vol 1. Encyclopedia of Neuroscience. Birkhauser, Boston, MA. Chapter 7: pp: 12-23.

Kubo K, Kanehisa H, Kawakami Y, Fukunaga T (2001) Influence of static stretching on viscoelastic properties of human tendon structures in vivo. J Appl Physiol (1985) 90:520527.

Kunitz D (2016) Lift: Fitness culture from naked Greeks and acrobats to jazzercize and Ninja warriors. Harper Wave, New York, NY, USA Chapter 4: pp:31-45.

Lamb GD, Westerblad H (2011) Acute effects of reactive oxygen and nitrogen species on the contractile function of skeletal muscle. J Physiol 589:2119-2127. doi:10.1113/jphysiol.2010.199059

Lee EJ, Joumaa V, Herzog W (2007) New insights into the passive force enhancement in skeletal muscles. J Biomech 40:719-727. doi:10.1016/j.jbiomech.2006.10.009

Lee RH, Heckman C (2000) Adjustable amplification of synaptic input in the dendrites of spinal motoneurons in vivo. The J Neurosci 20:6734-6740.

Leonard TR, Herzog W (2010) Regulation of muscle force in the absence of actin-myosin-based cross-bridge interaction. Am J Physiol Cell Physiol 299:C14-20. doi:10.1152/ajpcell.00049.2010

Lima CD, Brown LE, Wong MA, Leyva WD, Pinto RS, Cadore EL, Ruas CV (2016) Acute effects of static vs. ballistic stretching on strength and muscular fatigue between ballet dancers and resistance-trained women. J Strength Cond Res 30:3220-3227. doi:10.1519/JSC.0000000000001606

Lima CD, Behm, D.G.; Brown, L.E.; (2019) Acute effects of stretching on flexibility and preformance.: A Narrative Review. J Sci Sport Exerc 1:29-37.

Longo S, Ce E, Rampichini S, Devoto M, Venturelli M, Limonta E, Esposito F (2017) Correlation between stiffness and electromechanical delay components during muscle 
contraction and relaxation before and after static stretching. J Electromyogr Kinesiol 33:83-93. doi:10.1016/j.jelekin.2017.02.001

MacIntosh BR, MacNaughton MB (2005) The length dependence of muscle active force: considerations for parallel elasatic properties. J Appl Physiol 98:1666-1673.

Maganaris CN (2003) Force-length characteristics of the in vivo human gastrocnemius muscle. Clin Anat 16:215-223. doi:10.1002/ca.10064

Magnusson SP, Simonsen EB, Aagaard P, Boesen J, Johannsen F, Kjaer M (1997) Determinants of musculoskeletal flexibility: viscoelastic properties, cross-sectional area, EMG and stretch tolerance. Scand J Med Sci Sports 7:195-202.

Magnusson SP, Simonsen EB, Aagaard P, Kjaer M (1996a) Biomechanical responses to repeated stretches in human hamstring muscle in vivo. The Amer J Sports Med 24:622-627.

Magnusson SP, Simonsen EB, Aagaard P, Sorensen H, Kjaer M (1996b) A mechanism for altered flexibility in human skeletal muscle. J Physiol 497 ( Pt 1):291-298.

Marchetti PH et al. (2019) Different volumes and intensities of static stretching affect the range of motion and muscle force output in well-trained subjects. Sports Biomech:12:1-10. doi:10.1080/14763141.2019.1648540

Marchetti PHR, R.G.; Gomes, W.A.; da Silva, W.A.; Soares, E.G.; de Freitas, F.S.; Behm, D.G.; (2017) Static-stretching of the pectoralis major decreases tríceps brachii activation during a maximal isometric bench press. Gazzetta Medica Italiana 23:112-133.

Marcora SM, Staiano W, Manning V (2009) Mental fatigue impairs physical performance in humans. J Appl Physiol 106:857-864. doi:10.1152/japplphysiol.91324.2008

Mark RF, Coquery JM, Paillard J (1968) Autogenetic reflex effects of slow or steady stretch of the calf muscles in man. Exp Brain Res 6:130-145. doi:10.1007/BF00239167

Martinez-Jimenez EM et al. (2019) Acute effects of intermittent versus continuous bilateral ankle plantar flexor static stretching on postural sway and plantar pressures: A Randomized Clinical Trial. J Clin Med 8:43-51. doi:10.3390/jcm8010052

Mascarin NC, Vancini RL, Lira CA, Andrade MS (2015) Stretch-induced reductions in throwing performance are attenuated by warm-up before exercise. J Strength Cond Res 29:13931398. doi:10.1519/JSC.0000000000000752

Matsuo S et al. (2019) Changes in flexibility and force are not different after static versus dynamic stretching. Sports Med Int Open 3:E89-E95. doi:10.1055/a-1001-1993

Matthews PBC (1981) Muscle spindles: their messages and their fusimotor supply. In: Brooks VB (ed) The Nervous System: Handbook Of Physiology, vol II. American Physiological Society, pp 189-288.

Mayfield DL, Launikonis BS, Cresswell AG, Lichtwark GA (2016) Additional in-series compliance reduces muscle force summation and alters the time course of force relaxation during fixed-end contractions. J Exp Biol 219:3587-3596. doi:10.1242/jeb. 143123

McBride JM, Deane R, Nimphius S (2007) Effect of stretching on agonist-antagonist muscle activity and muscle force output during single and multiple joint isometric contractions. Scand J Med Sci Sports 17:54-60. doi:10.1111/j.1600-0838.2005.00495.x

McHugh MP, Nesse M (2008) Effect of stretching on strength loss and pain after eccentric exercise. Med Sci Sports Exerc 40:566-573. doi:10.1249/MSS.0b013e31815d2f8c

McHugh MP, Tallent J, Johnson CD (2013) The role of neural tension in stretch-induced strength loss. J Strength Cond Res 27:1327-1332. doi:10.1519/JSC.0b013e31828a1e73 
Mizuno T, Matsumoto M, Umemura Y (2014) Stretching-induced deficit of maximal isometric torque is restored within 10 minutes. J Strength Cond Res 28:147-153. doi:10.1519/JSC.0b013e3182964220

Moore RL, Stull JT (1984) Myosin light chain phosphorylation in fast and slow skeletal muscles in situ. Am J Physiol 247:C462-C471.

Morse CI, Degens H, Seynnes OR, Maganaris CN, Jones DA (2008) The acute effect of stretching on the passive stiffness of the human gastrocnemius muscle tendon unit. $\mathrm{J}$ Physiol 586:97-106. doi:10.1113/jphysiol.2007.140434

Murphy JR, Di Santo MC, Alkanani T, Behm DG (2010) Aerobic activity before and following short-duration static stretching improves range of motion and performance vs. a traditional warm-up. Appl Physiol Nutr Metab 35:679-690. doi:10.1139/H10-062

Nakamura M, Ikezoe T, Takeno Y, Ichihashi N (2011) Acute and prolonged effect of static stretching on the passive stiffness of the human gastrocnemius muscle tendon unit in vivo. J Orthop Res 29:1759-1763. doi:10.1002/jor.21445

Nelson AG, Allen JD, Cornwell A, Kokkonen J (2001a) Inhibition of maximal voluntary isometric torque production by acute stretching is joint-angle specific. Res Q Exerc Sport 72:68-70. doi:10.1080/02701367.2001.10608934

Nelson AG, Guillory IK, Cornwell C, Kokkonen J (2001b) Inhibition of maximal voluntary isokinetic torque production following stretching is velocity-specific. J Strength Cond Res 15:241-246.

Opplert J, Genty JB, Babault N (2016) Do stretch durations Aafect muscle mechanical and neurophysiological properties? Int J Sports Med 37:673-679. doi:10.1055/s-0042-104934

Opplert J, Paizis C, Papitsa A, Blazevich AJ, Cometti C, Babault N (2020) Static stretch and dynamic muscle activity induce acute similar increase in corticospinal excitability. Plos one $15: \mathrm{e} 0230388$.

Orban WAR (1962) Royal Canadian Air Force Exercise Plans for Physical Fitness. Queen's Printer, Ottawa, Ontario, Canada pp: 3-104.

Otsuki A, Fujita E, Ikegawa S, Kuno-Mizumura M (2011) Muscle oxygenation and fascicle length during passive muscle stretching in ballet-trained subjects. Int J Sports Med 32:496-502. doi:10.1055/s-0031-1275297

Pageaux B, Lepers R, Dietz KC, Marcora SM (2014) Response inhibition impairs subsequent self-paced endurance performance. Eur J Appl Physiol 114:1095-1105. doi:10.1007/s00421-014-2838-5

Pageaux B, Marcora SM, Lepers R (2013) Prolonged mental exertion does not alter neuromuscular function of the knee extensors. Med Sci Sports Exerc 45:2254-2264. doi:10.1249/MSS.0b013e31829b504a

Palmer TB, Pineda JG, Cruz MR, Agu-Udemba CC (2019) Duration-dependent effects of passive static stretching on musculotendinous stiffness and maximal and rapid torque and surface electromyography characteristics of the hamstrings. J Strength Cond Res 33:717726. doi:10.1519/JSC.0000000000003031

Palmer TB, Thiele RM (2019) Passive stiffness and maximal and explosive Ssrength responses after an acute bout of constant-tension stretching. J Athl Train 54:519-526. doi:10.4085/1062-6050-62-18

Palomero J, Pye D, Kabayo T, Jackson MJ (2012) Effect of passive stretch on intracellular nitric oxide and superoxide activities in single skeletal muscle fibres: influence of ageing. Free Radic Res 46:30-40. doi:10.3109/10715762.2011.637203 
Perry J, Bekey GA (1981) EMG-force relationships in skeletal muscle CRC Critical Reviews in Biomedical Engineering: 1-21

Phillips C, Powell T, Wiesendanger M (1971) Projection from low-threshold muscle afferents of hand and forearm to area 3a of baboon's cortex. J Physiol 217:419-446.

Power K, Behm DG, Cahill F, Carroll M, Young W (2004) An acute bout of static stretching: effects on force and jumping performance. Med Sci Sports Exerc 36:1389-1396.

Powers SK, Jackson MJ (2008) Exercise-induced oxidative stress: cellular mechanisms and impact on muscle force production. Physiol Rev 88:1243-1276. doi:10.1152/physrev.00031.2007

Prado LG, Makarenko I, Andresen C, Kruger M, Opitz CA, Linke WA (2005) Isoform diversity of giant proteins in relation to passive and active contractile properties of rabbit skeletal muscles. J Gen Physiol 126:461-480. doi:10.1085/jgp.200509364

Prochazka A, Ellaway P (2012) Sensory systems in the control of movement Comprehensive Physiology Chapter 11:187-209.

Pulverenti TS, Trajano GS, Kirk BJC, Blazevich AJ (2019) The loss of muscle force production after muscle stretching is not accompanied by altered corticospinal excitability. Eur $\mathrm{J}$ Appl Physiol 119:2287-2299. doi:10.1007/s00421-019-04212-8

Pulverenti TS, Trajano GS, Walsh A, Kirk BJC, Blazevich AJ (2020) Lack of cortical or Iaafferent spinal pathway involvement in muscle force loss after passive static stretching. $\mathrm{J}$ Neurophysiol 123:1896-1906. doi:10.1152/jn.00578.2019

Purslow PP (1989) Strain-induced reorientation of an intramuscular connective tissue network: implications for passive muscle elasticity J Biomech 22:21-31. doi:10.1016/00219290(89)90181-4

Raiteri BJ, Hahn D (2019) A reduction in compliance or activation level reduces residual force depression in human tibialis anterior. Acta Physiol (Oxf) 225:e13198. doi:10.1111/apha.13198

Rampichini S, Ce E, Limonta E, Esposito F (2014) Effects of fatigue on the electromechanical delay components in gastrocnemius medialis muscle. Eur J Appl Physiol 114:639-651. doi:10.1007/s00421-013-2790-9

Rassier DE, Leite FS, Nocella M, Cornachione AS, Colombini B, Bagni MA (2015) Noncrossbridge forces in activated striated muscles: a titin dependent mechanism of regulation? J Muscle Res Cell Motil 36:37-45. doi:10.1007/s10974-014-9397-6

Rathelot J-A, Strick PL (2009) Subdivisions of primary motor cortex based on corticomotoneuronal cells. Proceed National Academy Sci 106:918-923.

Reid JC, Greene R, Young JD, Hodgson DD, Blazevich AJ, Behm DG (2018) The effects of different durations of static stretching within a comprehensive warm-up on voluntary and evoked contractile properties. Eur J Appl Physiol 118:1427-1445. doi:10.1007/s00421018-3874-3

Rivas-Pardo JA, Eckels EC, Popa I, Kosuri P, Linke WA, Fernandez JM (2016) Work done by titin Ppotein folding assists muscle contraction. Cell Rep 14:1339-1347. doi:10.1016/j.celrep.2016.01.025

Roberts TJ et al. (2019) The multi-scale, three-dimensional nature of skeletal muscle contraction. Physiology (Bethesda) 34:402-408. doi:10.1152/physiol.00023.2019

Rode CS, T.; Herzog, W.; Blickhan, R. (2009) The effects of parallel and series elastic components on the active cat soleus force-length relationship. J Mechanics Medical Biol 9:105-122. 
Ryan ED, Herda TJ, Costa PB, Herda AA, Cramer JT (2014) Acute effects of passive stretching of the plantarflexor muscles on neuromuscular function: the influence of age. Age (Dordr) 36:9672. doi:10.1007/s11357-014-9672-x

Samson M, Button DC, Chaouachi A, Behm DG (2012) Effects of dynamic and static stretching within general and activity specific warm-up protocols. J Sports Sci Med 11:279-285.

Sato S, Kiyono R, Takahashi N, Yoshida T, Takeuchi K, Nakamura M (2020) The acute and prolonged effects of 20-s static stretching on muscle strength and shear elastic modulus. PLoS One 15:e0228583. doi:10.1371/journal.pone.0228583

Schieppati M, Nardone A, Musazzi M (1986) Modulation of the Hoffmann reflex by rapid muscle contraction or release. Hum-Neurobiol 5:59-66.

Schleip R (2003a) Fascial plasticity- a new neurobiological explanation: Part 2 J Bodywork Movt Ther 7:104-116.

Schleip R (2003b) Fascial plasticity- a new neurobiological explanation: Part I J Bodywork Movt Ther 7:11-19.

Silva GFA, A. R.; Andrade Rodrigues, S.; Szmuchrowski, L.A.; Dias da Silva, R.A.; Frummond, M.D.M.; (2018) The acute effect of a sport-specific stretching routine on the performance of vertical jumps in rhythmic gymnasts. J Exerc Physiol online 21:30-39.

Solomonow M, Baratta R, Shoji H, D' Ambrosia R (1990) The EMG-force relationship of skeletal muscle; dependence on contraction rate, and motor units control strategy. Electroencephalogr Clin Neurophysiol 30:141-152.

Stein RB (1995) Presynaptic inhibition in humans. Prog Neurobiol 47:533-544. doi:10.1016/0301-0082(95)00036-4

Stephenson DG, Williams DA (1985) Temperature-dependent calcium sensitivity changes in skinned muscle fibres of rat and toad. J Physiol 360:1-12. doi:10.1113/jphysiol.1985.sp015600

Stephenson DG, Wendt, I.R. (1984) Length dependence of changes in sarcoplasmic calcium concentration and myofibrillar calcium sensitivity in striated muscle fibres. J Muscle Res Cell Motility 5:243-272

Stevanovic VB, Jelic MB, Milanovic SD, Filipovic SR, Mikic MJ, Stojanovic MDM (2019) Sport-specific warm-up attenuates static stretching- induced negative effects on vertical jump but not neuromuscular excitability in basketball players. J Sports Sci Med 18:282289.

Sugi H, Abe T, Kobayashi T, Chaen S, Ohnuki Y, Saeki Y, Sugiura S (2013) Enhancement of force generated by individual myosin heads in skinned rabbit psoas muscle fibers at low ionic strength. PLoS One 8:e63658. doi:10.1371/journal.pone.0063658

Takeuchi K, Nakamura M (2020) Influence of high intensity 20 -second static stretching on the flexibility and strength of hamstrings. J Sports Sci Med 19:429-435.

Takeuchi K, Tsukuda F (2019) Comparison of the effects of static stretching on range of motion and jump height between quadriceps, hamstrings and triceps surae in collegiate basketball players. BMJ Open Sport Exerc Med 5:e000631. doi:10.1136/bmjsem-2019-000631

Taniguchi K, Shinohara M, Nozaki S, Katayose M (2015) Acute decrease in the stiffness of resting muscle belly due to static stretching. Scand J Med Sci Sports 25:32-40. doi: $10.1111 /$ sms. 12146

Tidball JG, Lavergne E, Lau KS, Spencer MJ, Stull JT, Wehling M (1998) Mechanical loading regulates NOS expression and activity in developing and adult skeletal muscle. Am J Physiol 275:C260-266. doi:10.1152/ajpcell.1998.275.1.C260 
Trajano GS, Nosaka K, Blazevich AJ (2017) Neurophysiological mechanisms underpinning stretch-induced force loss. Sports Med doi:10.1007/s40279-017-0682-6

Trajano GS, Nosaka K, L BS, Blazevich AJ (2014a) Intermittent stretch reduces force and central drive more than continuous stretch. Med Sci Sports Exerc 46:902-910. doi:10.1249/MSS.0000000000000185

Trajano GS, Seitz L, Nosaka K, Blazevich AJ (2013) Contribution of central vs. peripheral factors to the force loss induced by passive stretch of the human plantar flexors. J Appl Physiol (1985) 115:212-218. doi:10.1152/japplphysiol.00333.2013

Trajano GS, Seitz LB, Nosaka K, Blazevich AJ (2014b) Can passive stretch inhibit motoneuron facilitation in the human plantar flexors? J Appl Physiol (1985) 117:1486-1492. doi:10.1152/japplphysiol.00809.2014

Trajano GS, Seitz LB, Nosaka K, Blazevich AJ (2019) Passive muscle stretching impairs rapid force production and neuromuscular function in human plantar flexor.s Eur J Appl Physiol 119:2673-2684. doi:10.1007/s00421-019-04244-0

van den Berg F, Cabri, J. (1999) Angewandte Physiologie - Das Bindegewebe des Bewegungsapparates verstehen und beeinflussen. Georg Thieme Verlag, Stuttgart, Germany Chapter 5:154-175.

Vandenboom R, Gittings W, Smith IC, Grange RW, Stull JT (2013) Myosin phosphorylation and force potentiation in skeletal muscle: evidence from animal models. J Muscle Res Cell Motil 34:317-332. doi:10.1007/s10974-013-9363-8

Vandervoort AA, Quinlin J, McComas AJ (1983) Twitch potentiation after voluntary contraction. Exper Neurol 81:141-152.

Venturelli M, Ce E, Limonta,E, Bisconti AV, Devoto M, Rampichini S, et al. (2017) Central and peripheral responses to static and dynamic stretch of skeletal muscle: mechano- and metaboreflex implications. J Appl Physiol 122(1): 112-120. doi:10.1152/japplphysiol.00721.2016.

Venturelli M, Rampichini S, Coratella G, Limonta E, Bisconti AV, Ce E, et al. (2019) Heart and musculoskeletal hemodynamic responses to repetitive bouts of quadriceps static stretching. J Appl Physiol 127(2): 376-384. doi:10.1152/japplphysiol.00823.2018.

Vieira DCL, Alves de Almeida J, De Paula Santana HA, Da Cunha Nascimento D, Rodrigues da Silva F, Ernesto C (2019) Shorter static stretching volume does not impair isokinetic muscle strength. J Physical Educ Sport 19:141-1444.

Vieira TM, Bisi MC, Stagni R, Botter A (2017) Changes in tibialis anterior architecture affect the amplitude of surface electromyograms. J NeuroEngineering Rehabil 14(1): 81-84.

Walshe AD, Wilson GJ (1997) The influence of musculotendinous stiffness on drop jump performance. Can J Appl Physiol 22:117-132.

Ward SR, Winters TM, O'Connor SM, Lieber RL (2020) Non-linear scaling of passive mechanical properties in fibers, bundles, fascicles and whole rabbit muscles. Front Physiol 11:211. doi:10.3389/fphys.2020.00211

Weir DE, Tingley J, Elder GCB (2005) Acute passive stretching alters the mechanical properties of human plantar flexors and the optimal angle for maximal voluntary contraction. Eur $\mathrm{J}$ Appl Physiol 93:614-623.

Williams PE, Goldspink G (1984) Connective tissue changes in immobilised muscle. J Anat 138 (Pt 2):343-350.

Wilson G, Elliot B, Wood G (1992) Stretching shorten cycle performance enhancement through flexibility training. Med Sci Sports Exerc 24:116-123. 
Worrell T, Smith T, Winegardner J (1994) Effect of hamstring stretching on hamstring muscle performance. J Orthoped Sports Physical Therapy 20:154-159.

Wu G, Ekedahl R, Stark B, Carlstedt T, Nilsson B, Hallin RG (1999) Clustering of Pacinian corpuscle afferent fibres in the human median nerve. Exper Brain Res 126:399-409.

Young WB (2007) The use of static stretching in warm-up for training and competition. Int $\mathbf{J}$ Sports Physiol Perform 2:212-216.

Young WB, Behm DG (2003) Effects of running, static stretching and practice jumps on explosive force production and jumping performance. J Sports Med Phys Fitness 43:2127.

Zehr EP (2002) Considerations for use of the Hoffmann reflex in exercise studies. Eur J Appl Physiol 86:455-468. 
Table 1: Sample of acute static stretching studies since 2016 that have investigated strength and power performance variables.

Acronyms: BB: basketball, CMJ: countermovement jump, Hams: hamstrings, HF: hip flexion, KE: knee extension, KF: knee flexion, MVC: maximum voluntary contraction, NR: not reported, NS: non-significant, POD: point of discomfort, RA: recreationally active, RT: resistance trained, RTime: reaction time, PT: peak torque, Quads: quadriceps, Sed: sedentary. Shaded boxes highlight studies that recruited youth.

\begin{tabular}{|c|c|c|c|c|c|c|c|c|c|c|c|}
\hline Authors & $\mathrm{n}$ & $\begin{array}{l}\text { Age } \\
\text { (yrs) }\end{array}$ & $\begin{array}{l}\text { Trained } \\
\text { State }\end{array}$ & $\begin{array}{l}\text { Prior } \\
\text { aerobic } \\
\text { warm-up }\end{array}$ & $\begin{array}{l}\text { Stretching } \\
\text { volume }\end{array}$ & $\begin{array}{l}\text { Stretch } \\
\text { Intensity }\end{array}$ & $\begin{array}{l}\text { Stretched } \\
\text { Muscles }\end{array}$ & $\begin{array}{l}\text { Post- } \\
\text { stretch } \\
\text { Dynamic } \\
\text { activity }\end{array}$ & $\begin{array}{l}\text { Post- } \\
\text { Test } \\
\text { Time }\end{array}$ & ROM & Performance \\
\hline $\begin{array}{l}\text { Avloniti et } \\
\text { al. } 2016 \mathrm{a}\end{array}$ & $34 \mathrm{M}$ & $20.5 \pm 1.4$ & Trained & 8 min jog & $\begin{array}{l}10,15,20, \\
30,40,60 \mathrm{~s}\end{array}$ & POD & $\begin{array}{l}\text { Hip } \\
\text { adductors } \\
\text { extensors, } \\
\text { knee } \\
\text { extensors, } \\
\text { flexors, } \\
\text { PF }\end{array}$ & NR & $4 \mathrm{~min}$ & NR & $\begin{array}{l}15+20 \mathrm{~s} \\
\text { stretch } \\
10 \mathrm{~m} \text { sprint: } \\
2.8 \% \\
20 \mathrm{~m} \text { sprint: } \\
3.2 \% \\
10,30,40, \\
60 \mathrm{~s} \text { stretch } \\
\text { Sprints: NS } \\
\text { All } \\
\text { durations: } \\
\text { Agility: NS }\end{array}$ \\
\hline $\begin{array}{l}\text { Avloniti et } \\
\text { al. } 2016 \text { b }\end{array}$ & $40 \mathrm{M}$ & $\begin{array}{l}21.2 \pm 1.6 \\
20.8 \pm 0.8\end{array}$ & Trained & 8 min jog & $\begin{array}{l}1 \times 20,30, \\
40,60 \mathrm{~s} \\
2 \times 10 \mathrm{~s}, \\
3 \times 10 \mathrm{~s}, \\
4 \times 10 \mathrm{~s}, \\
6 \times 10 \mathrm{~s}\end{array}$ & POD & $\begin{array}{l}\text { Hip } \\
\text { adductors } \\
\text { extensors, } \\
\text { knee } \\
\text { extensors, } \\
\text { flexors, } \\
\text { PF }\end{array}$ & NR & $3 \mathrm{~min}$ & NR & $\begin{array}{l}20 \text { s stretch } \\
\text { both groups: } \\
10 \text { m sprint: } \\
2.2-2.8 \% \\
\text { All other } \\
\text { conditions } \\
\text { NS }\end{array}$ \\
\hline $\begin{array}{l}\text { Balci et al. } \\
2019\end{array}$ & $\begin{array}{l}8 \mathrm{M} \\
8 \mathrm{~F}\end{array}$ & $19.9 \pm 1.2$ & RA & No & $\begin{array}{l}30 \mathrm{~s} \\
45 \mathrm{~s}\end{array}$ & NR & $\begin{array}{l}\text { Lower } \\
\text { limbs }\end{array}$ & NR & Imm & NR & $\begin{array}{l}\text { CMJ } \\
30 \mathrm{~s}:+6.2 \%, \\
d=0.19 \\
45 \mathrm{~s}:+10.5 \%, \\
d=0.31\end{array}$ \\
\hline $\begin{array}{l}\text { Barbosa et } \\
\text { al. } 2020\end{array}$ & $11 \mathrm{M}$ & $21.5 \pm 2.4$ & Trained & $\begin{array}{l}3 / 5 \\
\text { conditions } \\
10 \mathrm{~min} \\
\text { jog }\end{array}$ & $30 \mathrm{~s}$ & POD & $\begin{array}{l}\text { Quads } \\
\text { Hams } \\
\text { PF }\end{array}$ & $\begin{array}{l}1 / 5 \\
\text { conditions } \\
10 \mathrm{~min} \\
\text { jog }\end{array}$ & Imm & NR & $\begin{array}{l}\text { CMJ } \\
\text { WU: } 1.5 \% \\
d=1.0 \\
\text { SS: } 1.5 \% \\
d=1.0\end{array}$ \\
\hline
\end{tabular}




\begin{tabular}{|c|c|c|c|c|c|c|c|c|c|c|c|}
\hline & & & & & & & & & & & $\begin{array}{l}\text { WU-SS: } \\
1.5 \% \mathrm{~d}=1.0 \\
\text { SS-WU: } \\
4.7 \% \mathrm{~d}=2.0\end{array}$ \\
\hline $\begin{array}{l}\text { Begovic et } \\
\text { al. } 2018\end{array}$ & $\begin{array}{l}8 \mathrm{M} \\
7 \mathrm{~F}\end{array}$ & $\begin{array}{l}27.1 \pm 3.7 \\
26.9 \pm 3.9\end{array}$ & Healthy & NR & $10 \times 30 \mathrm{~s}$ & $90-130^{0}$ & Quads & NR & Imm & NR & $\begin{array}{l}\text { Time delay } \\
\text { EMG-Force } \\
35.5 \% \\
d=0.21 \\
-18.4 \% \\
d=0.14 \\
7.5 \% \\
d=0.06\end{array}$ \\
\hline $\begin{array}{l}\text { Behm et al. } \\
2019\end{array}$ & $14 \mathrm{M}$ & $19-30$ & RA & $\begin{array}{l}5 \text { min } \\
\text { cycle }\end{array}$ & $\begin{array}{l}8 \times 30 s \\
(4 \mathrm{~min})\end{array}$ & POD & $\begin{array}{l}\text { Quads } \\
\text { Hams }\end{array}$ & NR & $1 \mathrm{~min}$ & $\begin{array}{l}\text { HF: } 5.1 \% \\
d=0.74\end{array}$ & $\begin{array}{l}\text { KE MVC: } \\
-7.7 \% \\
d=0.26 \\
\end{array}$ \\
\hline $\begin{array}{l}\text { Bertolaccini } \\
\text { et al. } 2019\end{array}$ & $18 \mathrm{M}$ & $19-40$ & RT & $\begin{array}{l}5 \text { min } \\
\text { treadmill }\end{array}$ & $\begin{array}{l}3 \text { exercises } \\
\times 3 \times 30 s \\
(2 \mathrm{~min} 30 \mathrm{~s})\end{array}$ & POD & Quads & NR & $5 \mathrm{~min}$ & NR & $\begin{array}{l}\text { Total } \\
\text { volume: NS } \\
\text { Positive bias: } \\
\text { increased \# } \\
\text { reps in last } \\
\text { set }\end{array}$ \\
\hline $\begin{array}{l}\text { Blazevich } \\
\text { et al. } 2018\end{array}$ & $20 \mathrm{M}$ & $21.1 \pm 3.1$ & Athletes & $\begin{array}{l}\text { Low } \\
\text { intensity3 } \\
\text { min jog, } \\
\text { series of } \\
5 \mathrm{~s} \text { high } \\
\text { knees and } \\
\text { butt kicks }\end{array}$ & $\begin{array}{l}1 \times 5 s \\
3 \times 10 s \\
(30 s)\end{array}$ & POD & $\begin{array}{l}\text { Quads } \\
\text { Hams } \\
\text { Plantar } \\
\text { flexors, } \\
\text { Shoulders } \\
\text { HF, } \\
\text { Adductors } \\
\text { Gluteals } \\
\end{array}$ & $\begin{array}{l}\text { Higher } \\
\text { intensity } 2 \\
\text { min jog } \\
\text { series of } \\
5 \mathrm{~s} \text { high } \\
\text { knees } \\
\text { and butt } \\
\text { kicks }\end{array}$ & $7 \mathrm{~min}$ & NR & $\begin{array}{l}\text { SJ, CMJ, DJ, } \\
\text { 20m sprint, } \\
\text { agility test: } \\
\text { NS }\end{array}$ \\
\hline $\begin{array}{l}\text { Bouvier et } \\
\text { al. } 2017\end{array}$ & $11 \mathrm{M}$ & $21.0 \pm 2.0$ & Trained & $\begin{array}{l}10 \text { submax } \\
\text { contractions }\end{array}$ & $\begin{array}{l}5 \times 30 s \\
(150 s) \\
\end{array}$ & POD & $\begin{array}{l}\text { Quads } \\
\text { PF }\end{array}$ & NR & $\mathrm{Imm}$ & NR & $\begin{array}{l}\text { MVC: } \\
-7.1 \text { to }-7.7 \%\end{array}$ \\
\hline $\begin{array}{l}\text { Brusco et } \\
\text { al. } 2018\end{array}$ & $20 \mathrm{M}$ & $18-28$ & Untrained & $\begin{array}{l}5 \text { min } \\
\text { cycle }\end{array}$ & $30 \mathrm{~s}$ & $\begin{array}{l}\text { Mild } \\
\text { discomfort }\end{array}$ & $\begin{array}{l}\text { Quads } \\
\text { Hams } \\
\text { Glutes } \\
\text { PF }\end{array}$ & NR & Imm & NR & $\begin{array}{l}\text { CMJ: }-3.2 \% \\
D=0.16\end{array}$ \\
\hline $\begin{array}{l}\text { Caldwell et } \\
\text { al. } 2019\end{array}$ & $\begin{array}{l}22 \mathrm{M} \\
18 \mathrm{~F}\end{array}$ & $\begin{array}{l}23.6 \pm 7.5 \\
21.7 \pm 2.5\end{array}$ & RT & $\begin{array}{l}5 \text { min } \\
\text { cycle }\end{array}$ & $\begin{array}{l}4 \times 30 \mathrm{~s} \\
(2 \mathrm{~min})\end{array}$ & POD & Hams & NR & $1 \mathrm{~min}$ & NR & $\begin{array}{l}\text { KE MVC: }- \\
-8.1 \% d=0.3 \\
\text { DJ: }+9.2 \% \\
d=0.18\end{array}$ \\
\hline
\end{tabular}




\begin{tabular}{|c|c|c|c|c|c|c|c|c|c|c|c|}
\hline $\begin{array}{l}\text { Ce et al. } \\
2020\end{array}$ & $21 \mathrm{M}$ & $22 \pm 3$ & RA & NR & $\begin{array}{l}5 \mathrm{x} 45 \mathrm{~s} \\
(225 \mathrm{~s})\end{array}$ & $\begin{array}{l}80-90 \% \\
\text { POD }\end{array}$ & Quads & NR & $\begin{array}{l}\text { Imm, 5, } \\
10 \mathrm{~min}\end{array}$ & $6-11 \%$ & $\begin{array}{l}\text { KE MVC: } \\
-7 \text { to }-19 \%\end{array}$ \\
\hline $\begin{array}{l}\text { Chatzopoulos } \\
\text { et al. } 2019\end{array}$ & $25 \mathrm{M}$ & $11.8 \pm 1.6$ & $\begin{array}{l}\text { Athletes } \\
\text { TaeKwon } \\
\text { Do }\end{array}$ & $\begin{array}{l}5 \mathrm{~min} \\
\text { jog }\end{array}$ & $30 \mathrm{~s}$ & $\begin{array}{l}\text { Mild } \\
\text { discomfort }\end{array}$ & $\begin{array}{l}\text { Quads, } \\
\text { Hams, } \\
\text { Iliopsoas }\end{array}$ & NR & $\mathrm{Imm}$ & $\begin{array}{l}\text { Hams: } 5.6 \% \\
d=0.44\end{array}$ & $\begin{array}{l}\text { RTime: } \\
-1.7 \% \\
d=0.09 \\
\text { Force Sense } \\
-14.04 \% \\
d=0.22\end{array}$ \\
\hline $\begin{array}{l}\text { Celebi et al. } \\
2016\end{array}$ & $30 \mathrm{M}$ & $\begin{array}{l}21.5 \pm 3.7 \\
18.7 \pm 0.5\end{array}$ & $\begin{array}{l}\text { Sed: } 15 \\
\text { Soccer: } 15\end{array}$ & $\begin{array}{l}5 \text { min } \\
\text { cycle }\end{array}$ & $20 \mathrm{~min}$ & POD & Quads & NR & $\mathrm{Imm}$ & $\begin{array}{l}\text { Sed: } 8.8 \% \\
d=0.37 \\
\text { Soccer: } 5.1 \% \\
d=0.21\end{array}$ & $\begin{array}{l}\text { KE } \\
\text { Isokinetic } \\
\text { PT: NS }\end{array}$ \\
\hline $\begin{array}{l}\text { De Souza et } \\
\text { al. } 2019\end{array}$ & $\begin{array}{l}11 \mathrm{M} \\
10 \mathrm{~F}\end{array}$ & $\begin{array}{l}22.5 \pm 2.1 \\
25.6 \pm 5.1\end{array}$ & Untrained & NR & $\begin{array}{l}3 \times 30 s \\
(90 s)\end{array}$ & POD & Hams & NR & $\begin{array}{l}\text { Imm, } \\
1,3,5 \\
\text { min }\end{array}$ & NR & $\begin{array}{l}\text { Hams PT } \\
\text { Imm: }-33.6 \% \\
d=1.6 \\
1 \mathrm{~min}: \\
-12.5 \% \\
d=0.52 \\
3 \text { min: NS } \\
5 \text { min: NS }\end{array}$ \\
\hline $\begin{array}{l}\text { Fjerstad et } \\
\text { al. } 2018\end{array}$ & $\begin{array}{l}20 \mathrm{M} \\
20 \mathrm{~F}\end{array}$ & $\begin{array}{l}22.5 \pm 1.8 \\
23.6 \pm 4.2\end{array}$ & $\begin{array}{l}\text { Limited } \\
\text { flexibility }\end{array}$ & Yes & NR & $70 \%$ POD & $\begin{array}{l}\text { Hip } \\
\text { Adductors }\end{array}$ & NR & Imm & $\begin{array}{l}\text { Passive: } 1.8 \% \\
\mathrm{~d}=0.21 \\
\text { Active: } 2.2 \% \\
\mathrm{~d}=0.28\end{array}$ & $\begin{array}{l}\text { MVC } \\
\text { Passive:3.4\% } \\
d=0.11 \\
\text { Active: } 1.2 \% \\
d=0.04\end{array}$ \\
\hline $\begin{array}{l}\text { Freitas et al. } \\
2016\end{array}$ & $17 \mathrm{M}$ & $22.1 \pm 2.7$ & $\begin{array}{l}\text { Limited } \\
\text { flexibility }\end{array}$ & NR & $\begin{array}{l}900 \mathrm{~s} \\
\text { (LILD) } \\
243.5 \\
\pm 69.5 \mathrm{~s} \\
\text { (HISD) }\end{array}$ & $\begin{array}{l}50 \% \max \\
\text { passive } \\
\text { torque } \\
100 \% \\
\text { passive } \\
\text { torque }\end{array}$ & Hams & NR & $\begin{array}{l}1,30 \\
60 \mathrm{~min}\end{array}$ & $\begin{array}{l}\text { HISD ROM } \\
\text { sig greater } \\
\text { than LILD }\end{array}$ & NR \\
\hline $\begin{array}{l}\text { Hatano et } \\
\text { al. } 2019\end{array}$ & $\begin{array}{l}11 \mathrm{M} \\
13 \mathrm{~F} \\
\end{array}$ & $20.5 \pm 1.1$ & Healthy & NR & $300 \mathrm{~s}$ & $\begin{array}{l}\text { Maximum } \\
\text { extension }\end{array}$ & Quads & NR & $\begin{array}{l}10,20, \\
30 \mathrm{~min}\end{array}$ & NR & $\begin{array}{l}\text { MVC: } \\
-1.8 \text { to } 2.5 \%\end{array}$ \\
\hline $\begin{array}{l}\text { Ikeda et al. } \\
2019\end{array}$ & $10 \mathrm{M}$ & $22 \pm 2$ & RA & NR & $\begin{array}{l}15 \times 1 \mathrm{~min} \\
(15 \mathrm{~min})\end{array}$ & $\begin{array}{l}\text { Subtle } \\
\text { pain } \\
\text { sensation }\end{array}$ & $\begin{array}{l}\text { Plantar } \\
\text { flexors }\end{array}$ & NR & $\begin{array}{l}\text { Imm, } \\
15,30, \\
60 \mathrm{~min}\end{array}$ & $\begin{array}{l}\text { Imm: } 7.2 \% \\
15: 0.4 \% \\
30: 0.2 \% \\
60:-1.0 \%\end{array}$ & $\begin{array}{l}\text { PF torque } \\
-4.3 \% \\
d=0.26\end{array}$ \\
\hline $\begin{array}{l}\text { Janes et al. } \\
2016\end{array}$ & $28 \mathrm{M}$ & $\begin{array}{l}21.8 \pm 1.3 \\
21.4 \pm 2.0\end{array}$ & $\begin{array}{l}\text { Biased:14 } \\
\text { Deception:14 }\end{array}$ & $\begin{array}{l}5 \text { min } \\
\text { cycle }\end{array}$ & $\begin{array}{l}3 \times 30 s \\
(90 s)\end{array}$ & POD & Hams & NR & $\begin{array}{l}1 \mathrm{~min} \\
5 \mathrm{~min}\end{array}$ & NR & $\begin{array}{l}\text { KE MVC } \\
\text { Biased: - } \\
-3.6- \\
\end{array}$ \\
\hline
\end{tabular}




\begin{tabular}{|c|c|c|c|c|c|c|c|c|c|c|c|}
\hline & & & & & & & & & & & $\begin{array}{l}-10.4 \%, \\
d=0.06 \\
\text { Deception: } \\
\text { NS }\end{array}$ \\
\hline $\begin{array}{l}\text { Kataura et } \\
\text { al. } 2017\end{array}$ & $\begin{array}{l}9 \mathrm{M} \\
9 \mathrm{~F}\end{array}$ & $20.6 \pm 1.2$ & Untrained & NR & $180 \mathrm{~s}$ & $\begin{array}{l}80 \%, \\
100 \%, \\
120 \% \text { of } \\
\text { pain onset }\end{array}$ & Hams & NR & Imm & $\begin{array}{l}80 \%:-0.2 \% \\
100 \%: 6.4 \% \\
120 \%: 7.8 \%\end{array}$ & $\begin{array}{l}\text { MVC } \\
80 \%: \mathrm{NS} \\
100 \%: \\
-3.3 \mathrm{Nm} \text { Sig } \\
120 \%: \\
-2.9 \mathrm{Nm} \mathrm{Sig}\end{array}$ \\
\hline $\begin{array}{l}\text { Konrad et } \\
\text { al. } 2017 \text { a }\end{array}$ & $\begin{array}{l}9 \mathrm{M} \\
8 \mathrm{~F}\end{array}$ & $\begin{array}{l}24.9 \pm 4.2 \\
23.3 \pm 2.5\end{array}$ & Healthy & NR & $\begin{array}{l}4 \times 30 \mathrm{~s} \\
(2 \mathrm{~min})\end{array}$ & $\begin{array}{l}95 \% \max \\
\text { ROM }\end{array}$ & PF & NR & $<5 \min$ & $\begin{array}{l}15.4 \% \\
d=0.72 \\
21.9 \% \\
d=1.24\end{array}$ & $\begin{array}{l}\text { MVC: } \\
-1.4, d=0.03 \\
-3.3 \%, \\
d=0.08\end{array}$ \\
\hline $\begin{array}{l}\text { Konrad et } \\
\text { al. } 2017 \mathrm{~b}\end{array}$ & $\begin{array}{l}21 \mathrm{M} \\
4 \mathrm{~F} \\
\end{array}$ & $\begin{array}{l}23.3 \pm 2.5 \\
23.4 \pm 3.7 \\
\end{array}$ & Trained & NR & $\begin{array}{l}4 \times 30 s \\
(2 \mathrm{~min})\end{array}$ & $\begin{array}{l}\text { Max } \\
\text { ROM }\end{array}$ & $\mathrm{PF}$ & NR & $2 \min$ & $\begin{array}{l}4.5 \% \\
d=0.24\end{array}$ & $\begin{array}{l}\text { MVC: } 0.3 \% \\
\mathrm{~d}=0.08\end{array}$ \\
\hline $\begin{array}{l}\text { Konrad et } \\
\text { al. } 2019\end{array}$ & $\begin{array}{l}7 \mathrm{M} \\
7 \mathrm{~F}\end{array}$ & $\begin{array}{l}27.5 \pm 8.3 \\
24.9 \pm 3.1\end{array}$ & Healthy & NR & $\begin{array}{l}5 \times 60 \mathrm{~s} \\
(5 \mathrm{~min})\end{array}$ & $\begin{array}{l}\text { Max } \\
\text { ROM }\end{array}$ & $\mathrm{PF}$ & NR & $\begin{array}{l}\text { Imm, } 5, \\
10 \mathrm{~min}\end{array}$ & $\begin{array}{l}16.5 \%, \\
d=0.67 \\
11.4 \% \\
d=0.45 \\
9.6 \% \\
d=0.47\end{array}$ & $\begin{array}{l}\text { MVC: } \\
-21.5 \%, \\
d=0.54 \\
-7.1 \% \\
d=0.21 \\
-15.3 \% \\
d=0.36\end{array}$ \\
\hline $\begin{array}{l}\text { Konrad and } \\
\text { Tilp 2020b }\end{array}$ & $\begin{array}{l}11 \mathrm{M} \\
3 \mathrm{~F}\end{array}$ & $\begin{array}{l}24.8 \pm 3.8 \\
24.6 \pm 2.3\end{array}$ & Healthy & NR & $\begin{array}{l}3 \times 60 \mathrm{~s} \\
(3 \mathrm{~min})\end{array}$ & $\mathrm{PF}$ & $\mathrm{PF}$ & NR & $\begin{array}{l}\mathrm{Imm}, \\
5 \mathrm{~min}\end{array}$ & $\begin{array}{l}13.8 \%, \\
d=0.43 \\
11.3 \%, \\
d=0.31\end{array}$ & $\begin{array}{l}\text { MVC: } \\
-4.3 \% \\
d=0.13 \\
1.2 \% \\
d=0.03\end{array}$ \\
\hline $\begin{array}{l}\text { Konrad and } \\
\text { Tilp 2020a }\end{array}$ & $\begin{array}{l}11 \mathrm{M} \\
14 \mathrm{~F}\end{array}$ & $\begin{array}{l}25.9 \pm 6.9 \\
24.1 \pm 2.7\end{array}$ & Trained & NR & $\begin{array}{l}2 \times 30 \mathrm{~s} \\
(1 \mathrm{~min})\end{array}$ & $\begin{array}{l}\text { Max } \\
\text { ROM }\end{array}$ & $\mathrm{PF}$ & NR & $\begin{array}{l}\text { Imm, } \\
20,40 \\
\min \end{array}$ & $\begin{array}{l}\text { Imm: } 12.2 \% \\
d=0.72 \\
20 \text { min: } \\
10.8 \% \\
d=0.67 \\
40 \text { min: } \\
12.8 \% \\
d=0.89\end{array}$ & $\begin{array}{l}\text { MVC } \\
\text { Imm: }-6.3 \% \\
D=0.18 \\
20 \text { min: } \\
-6.2 \% \\
d=0.17 \\
40 \text { in } \\
-7.5 \% \\
d=0.22\end{array}$ \\
\hline
\end{tabular}




\begin{tabular}{|c|c|c|c|c|c|c|c|c|c|c|c|}
\hline $\begin{array}{l}\text { Lima et al. } \\
2016\end{array}$ & $27 \mathrm{~F}$ & $23.8 \pm 1.8$ & $\begin{array}{l}15 \mathrm{RT} \\
12 \text { ballet }\end{array}$ & $\begin{array}{l}2 \times 10 \mathrm{~m} \text { of } \\
\text { knee } \\
\text { hugs, } \\
\text { lunges, } \\
\text { walking } \\
\text { toe } \\
\text { touches, }\end{array}$ & $\begin{array}{l}3 \times 30 s \\
(90 s)\end{array}$ & $\begin{array}{l}\text { Maximum } \\
\text { ROM }\end{array}$ & $\begin{array}{l}\text { Quads } \\
\text { Hams }\end{array}$ & NR & $3 \mathrm{~min}$ & $\begin{array}{l}\text { RT: } 9.04 \% \\
d=0.43 \\
\text { Ballet: } 2.7 \% \\
d=0.42\end{array}$ & $\begin{array}{l}\text { Quads and } \\
\text { Hams PT: } \\
\text { NS }\end{array}$ \\
\hline $\begin{array}{l}\text { Longo et al. } \\
2017\end{array}$ & $18 \mathrm{M}$ & $24.3 \pm 3.0$ & RA & NR & $\begin{array}{l}6 \times 45 \mathrm{~s} \\
(4.5 \mathrm{~min})\end{array}$ & POD & $\mathrm{PF}$ & NR & Imm & $\begin{array}{l}16.6 \% \\
d=0.85\end{array}$ & $\begin{array}{l}\text { MVC } \\
-14.1 \%, \\
d=1.1\end{array}$ \\
\hline $\begin{array}{l}\text { Marchetti et } \\
\text { al. } 2019\end{array}$ & $15 \mathrm{M}$ & $27.5 \pm 6.1$ & RT & $\begin{array}{l}5 \text { min } \\
\text { cycle }\end{array}$ & $\begin{array}{l}50 \%: 6 x \\
40 s(240 s) \\
85 \%: 3 x 40 s \\
(120 s)\end{array}$ & $\begin{array}{l}50 \% \\
85 \% \\
\text { POD }\end{array}$ & Hams & NR & NR & $\begin{array}{l}50 \% \text { POD: } \\
4.6 \% \\
d=0.55 \\
85 \% \text { POD } \\
11.4 \% \\
d=1.3 \\
\end{array}$ & $\begin{array}{l}\text { KF force } \\
-23.6 \%, \\
d=1.37\end{array}$ \\
\hline $\begin{array}{l}\text { Martinez- } \\
\text { Jimenez et } \\
\text { al. } 2019\end{array}$ & $\begin{array}{l}42 \mathrm{~F} \\
6 \mathrm{M}\end{array}$ & $32.1 \pm 7.6$ & Healthy & NR & $\begin{array}{l}\text { Continuous: } \\
1 \times 2 \text { min } \\
\text { Intermittent } \\
5 \times 1 \text { min }\end{array}$ & $70 \%$ POD & $\begin{array}{l}\text { Plantar } \\
\text { flexors }\end{array}$ & NR & Imm & NR & $\begin{array}{l}\text { Intermittent } \\
\text { ML } \\
\text { displacement } \\
10.8 \% \\
d=0.36 \\
\text { Continuous } \\
4.3 \% \\
d=0.09 \\
\end{array}$ \\
\hline $\begin{array}{l}\text { Matsuo et } \\
\text { al. } 2019\end{array}$ & $16 \mathrm{M}$ & $22.2 \pm 1.2$ & Healthy & NR & $\begin{array}{l}10 \times 30 \mathrm{~s} \\
(5 \mathrm{~min})\end{array}$ & $\begin{array}{l}\text { Tolerable } \\
\text { without } \\
\text { pain } \\
\end{array}$ & Hams & NR & Imm & $\begin{array}{l}16.7 \% \\
d=2.2\end{array}$ & $\begin{array}{l}\text { KF MVC } \\
-14.3 \% \\
d=0.61 \\
\end{array}$ \\
\hline $\begin{array}{l}\text { Opplert et } \\
\text { al. } 2016\end{array}$ & $10 \mathrm{M}$ & $24.0 \pm 1.5$ & RA & NR & $\begin{array}{l}1,2,3,4,10 \times \\
30 \mathrm{~s}\end{array}$ & POD & $\mathrm{PF}$ & NR & $\begin{array}{l}\mathrm{Imm}, \\
5 \mathrm{~min}\end{array}$ & & $\begin{array}{l}\text { MVC: }-5.4 \% \\
\text { RFD: }-2.8 \%\end{array}$ \\
\hline $\begin{array}{l}\text { Palmer et } \\
\text { al. } 2019\end{array}$ & $13 \mathrm{~F}$ & $21 \pm 2$ & RA & NR & $\begin{array}{l}1 \times 30 s \\
2 \times 30 s(60 s) \\
4 \times 30 s \\
(120 s)\end{array}$ & POD & Hams & NR & $\mathrm{Imm}$ & $\begin{array}{l}30 \mathrm{~s}: 9.04 \% \\
d=0.56 \\
60 \mathrm{~s}: 7.8 \% \\
d=0.39 \\
120 \mathrm{~s}: 9.9 \% \\
d=0.44\end{array}$ & $\begin{array}{l}30 \mathrm{~s}:-4.2 \% \\
d=0.17 \\
60 \mathrm{~s}:+1.4 \% \\
d=0.05 \\
120 \mathrm{~s}:+1.0 \% \\
d=0.04\end{array}$ \\
\hline $\begin{array}{l}\text { Palmer and } \\
\text { Thiele } 2019\end{array}$ & $11 \mathrm{~F}$ & $24 \pm 4$ & RA & NR & $\begin{array}{l}4 \times 15 s \\
(1 \mathrm{~min})\end{array}$ & POD & Hams & NR & Imm & & $\begin{array}{l}\text { MVC: } 0.6 \%, \\
d=0.02 \\
\text { RTD: } 4.8 \%, \\
d=0.17\end{array}$ \\
\hline
\end{tabular}




\begin{tabular}{|c|c|c|c|c|c|c|c|c|c|c|c|}
\hline $\begin{array}{l}\text { Reid et al. } \\
2018\end{array}$ & $16 \mathrm{M}$ & $27.6 \pm 2.2$ & RT & $\begin{array}{l}5 \text { min } \\
\text { cycle }\end{array}$ & $30,60,120 \mathrm{~s}$ & POD & $\begin{array}{l}\text { Quads } \\
\text { Hams }\end{array}$ & $\begin{array}{l}\text { Dynamic } \\
\text { stretch } \\
\text { and } \\
\text { activities }\end{array}$ & $\begin{array}{l}\text { After } \\
\text { warm- } \\
\text { up, SS, } \\
\text { DS/DA, } \\
10 \mathrm{~min}\end{array}$ & $\begin{array}{l}\text { HF: } 2.6 \%- \\
4.7 \% \\
d=0.2-0.5 \\
\text { KF: } 6.4- \\
9.2 \% \\
d=0.3-0.4\end{array}$ & $\begin{array}{l}\text { Quad MVC } \\
-1.7 \text { to }-4.4 \% \\
d=0.1-0.2 \\
\text { VJ } \\
-1.8 \%-1.1 \% \\
d=0.1\end{array}$ \\
\hline $\begin{array}{l}\text { Saka et al. } \\
2020\end{array}$ & $8 \mathrm{M}$ & $21.6 \pm 2.3$ & Untrained & NR & $15 \mathrm{~s}$ & POD & $\begin{array}{l}\text { Quads } \\
\text { Hams PF } \\
\text { Hip } \\
\text { Adductor } \\
\text { Hip } \\
\text { Extensors }\end{array}$ & NR & Imm & NR & $\begin{array}{l}\text { VJ: } 12.1 \% \\
d=1.6\end{array}$ \\
\hline $\begin{array}{l}\text { Sato et al. } \\
2020\end{array}$ & $20 \mathrm{M}$ & $21 \pm 0.2$ & Non-athletic & $\begin{array}{l}5 \text { min } \\
\text { cycle }\end{array}$ & $20-\mathrm{s}$ & NR & $\begin{array}{l}\text { Plantar } \\
\text { flexors }\end{array}$ & NR & $\begin{array}{l}\text { Imm, } 5, \\
10 \mathrm{~min}\end{array}$ & $\begin{array}{l}24.1 \% \\
d=0.86\end{array}$ & $\begin{array}{l}\text { Conc/Ecc } \\
\text { torque } \\
\text { NS } \\
\end{array}$ \\
\hline $\begin{array}{l}\text { Silva et al. } \\
2018\end{array}$ & $13 \mathrm{~F}$ & $14.5 \pm 2.4$ & $\begin{array}{l}\text { Athletes } \\
\text { Gymnasts }\end{array}$ & $\begin{array}{l}5 \text { min jog } \\
5 \text { min } \\
\text { walk } \\
8 \mathrm{CMJ}\end{array}$ & $\begin{array}{l}4 \text { Hams } \\
3 \text { Adductor } \\
2 \text { Quads } \\
\text { stretches of } \\
90 \text { s each }\end{array}$ & $\begin{array}{l}\text { Maximum } \\
\text { ROM }\end{array}$ & $\begin{array}{l}\text { Hams, } \\
\text { Quads, } \\
\text { Adductors }\end{array}$ & $\begin{array}{l}7 \\
\text { dynamic } \\
\text { stretches }\end{array}$ & Imm & $\begin{array}{l}\text { Change } \\
\text { NR }\end{array}$ & $\begin{array}{l}\text { CMJ: }-8.1 \% \\
d=0.73\end{array}$ \\
\hline $\begin{array}{l}\text { Stevanovic } \\
\text { et al. } 2018\end{array}$ & $12 \mathrm{M}$ & $18 \pm 0.4$ & $\begin{array}{l}\text { Athletes } \\
\text { (BB) }\end{array}$ & $6 \mathrm{~min}$ jog & 6-min & NR & $\begin{array}{l}\text { Lower } \\
\text { limbs }\end{array}$ & $\begin{array}{l}8 \min \\
\mathrm{BB}\end{array}$ & $\begin{array}{l}\text { Imm } \\
\text { and } \\
\text { after } 8 \\
\text { min BB }\end{array}$ & NR & $\begin{array}{l}\text { VJ } \\
\text { Imm:-3.01\% } \\
d=1.13 \\
\text { Post-BB: NS } \\
d=0.26\end{array}$ \\
\hline $\begin{array}{l}\text { Takeuchi \& } \\
\text { Tsukuda } \\
2019\end{array}$ & $14 \mathrm{M}$ & $20.2 \pm 0.7$ & $\begin{array}{l}\text { Athletes } \\
\text { (BB) }\end{array}$ & NR & 5-min & NR & $\begin{array}{l}\text { Quads } \\
\text { Hams } \\
\text { Plantar } \\
\text { Flexors }\end{array}$ & NR & NR & $\begin{array}{l}\text { Quads: } 1.8 \% \\
d=0.26 \\
\text { Hams: } 8.9 \% \\
d=0.52 \\
\text { PF: } 5.7 \% \\
d=0.38\end{array}$ & $\begin{array}{l}\text { Quads VJ: } \\
\text { NS } \\
\text { Hams VJ: } \\
\text { NS } \\
\text { PF VJ: } \\
-3.3 \% \\
d=0.34\end{array}$ \\
\hline $\begin{array}{l}\text { Trajano et } \\
\text { al. } 2019\end{array}$ & $18 \mathrm{M}$ & $26.8 \pm 4.5$ & RA & $\begin{array}{l}5 \text { min } \\
\text { cycle }\end{array}$ & $\begin{array}{l}\text { Continuous } \\
1 \times 5 \text { min } \\
\text { Intermittent } \\
5 \times 1 \text { min }\end{array}$ & $\begin{array}{l}\text { Maximum } \\
\text { tolerable }\end{array}$ & $\begin{array}{l}\text { Plantar } \\
\text { Flexors }\end{array}$ & NR & $\begin{array}{l}\text { Imm, } \\
15,30 \\
\min \end{array}$ & NR & $\begin{array}{l}\text { RTD: } \\
\text { Cont:-30.2\% } \\
\text { Inter: }-15.1 \%\end{array}$ \\
\hline $\begin{array}{l}\text { Vieira et al. } \\
2019\end{array}$ & $14 \mathrm{M}$ & $22.05 \pm 2.1$ & Trained & $\begin{array}{l}5 \text { min } \\
\text { cycle }+ \\
\text { Stretch }\end{array}$ & $20,40,60 \mathrm{~s}$ & POD & $\begin{array}{l}\text { Hip and } \\
\text { Knee } \\
\text { Flexion }\end{array}$ & NR & Imm & NR & $\begin{array}{l}\text { KE PT } \\
\left(60^{0} / \mathrm{s}\right) \\
20 \mathrm{~s}:-5.9 \% \\
d=0.49\end{array}$ \\
\hline
\end{tabular}




\begin{tabular}{|c|c|c|c|c|c|c|c|c|c|c|c|}
\hline & & & & & & & & & & & $\begin{array}{l}40 \mathrm{~s}:-1.9 \% \\
d=0.14 \\
60 \mathrm{~s}:-4.1 \% \\
d=0.36\end{array}$ \\
\hline $\begin{array}{l}\text { Descriptive } \\
\text { Statistics } \\
\text { (i.e. sums, } \\
\text { means, } \\
\text { frequencies) } \\
42 \text { studies }\end{array}$ & $\begin{array}{l}605 \mathrm{M} \\
218 \mathrm{~F} \\
26.4 \% \\
\text { female }\end{array}$ & $\begin{array}{l}26.6 \pm 3.31 \\
\text { yrs } \\
\text { Only } 2 \\
\text { youth } \\
\text { studies }\end{array}$ & $\begin{array}{l}18 \text { studies: } \\
\text { trained } \\
8 \text { studies: } \\
\text { RA } \\
13 \text { studies: } \\
\text { untrained or } \\
\text { healthy } \\
2 \text { studies: } \\
\text { limited } \\
\text { flexibility } \\
1 \text { study: } \\
\text { deception }\end{array}$ & $\begin{array}{l}21 / 42 \\
\text { included a } \\
\text { warm-up } \\
(50 \%)\end{array}$ & $\begin{array}{l}26 / 42 \text { used } \\
>60 \text { s SS } \\
\text { exclusively } \\
(61.9 \%)\end{array}$ & $\begin{array}{l}25 / 42 \\
\text { used } \\
\text { maximum } \\
\text { intensity / } \\
\text { ROM / } \\
\text { POD } \\
\text { exclusively } \\
(59.5 \%)\end{array}$ & $\begin{array}{l}1 / 42 \\
\text { stretched } \\
\text { upper } \\
\text { body: } \\
\text { shoulders } \\
(2.3 \%) \\
\text { All } \\
\text { studies } \\
\text { stretched } \\
\text { lower } \\
\text { body }\end{array}$ & $\begin{array}{l}5 / 42 \text { used } \\
\text { post- } \\
\text { stretch } \\
\text { dynamic } \\
\text { stretches } \\
\text { or } \\
\text { activities } \\
(11.9 \%)\end{array}$ & $\begin{array}{l}16 / 42 \\
\text { tested } \\
\text { at } 5 \\
\text { min or } \\
\text { more } \\
\text { post- } \\
\text { stretch } \\
(38.1 \%)\end{array}$ & $\begin{array}{l}8.04 \% \text { mean } \\
\text { increase in } \\
\text { ROM } \\
36 \text { increases } \\
\text { and } 2 \\
\text { decreases in } \\
\text { ROM }(-0.2 \% \\
\text { and }-1.0 \%) \\
\\
\text { Mean effect } \\
\text { size: } \\
d=0.60 \\
\text { (moderate } \\
\text { magnitude) }\end{array}$ & $\begin{array}{l}1.5 \% \text { mean } \\
\text { decrease in } \\
\text { performance } \\
\text { measures. } \\
40 \text { negative } \\
\text { and } 23 \\
\text { positive } \\
\text { measures. } \\
\text { Mean effect } \\
\text { size d=0.40 } \\
\text { (small } \\
\text { magnitude) }\end{array}$ \\
\hline
\end{tabular}


Table 2. Summary of evidence for/against the effects of neurological factors on the SS-induced force loss.

\begin{tabular}{|c|c|c|}
\hline Neurological Factor & Likelihood & Notes \\
\hline \multicolumn{3}{|l|}{ Voluntary activation } \\
\hline$-\mathrm{EMG}$ & Unclear & $\begin{array}{l}\text { EMG research is conflicting, with both } \\
\text { decreases and no changes reported, which is } \\
\text { most likely due to contrasting central and } \\
\text { peripheral (i.e. M wave) influences as well as } \\
\text { the curvilinear EMG-force relationship. As } \\
\text { EMG is more variable, large but not small force } \\
\text { reductions tend to show decreases in EMG. }\end{array}$ \\
\hline -EMG / M wave & Likely & $\begin{array}{l}\text { With EMG normalised to the } \mathrm{M} \text { wave there is a } \\
\text { consistent relationship with SS-induced force } \\
\text { loss. }\end{array}$ \\
\hline H-reflex: Ia afferents & Unlikely & Reduction in Ia and Ib reflex activity can occur \\
\hline GTO: Ib afferents & Unlikely & $\begin{array}{l}\text { during SS but desists rapidly following the } \\
\text { stretch (transient post-stretch duration). }\end{array}$ \\
\hline E-reflex & Possible & $\begin{array}{l}\text { E-reflexes can suppress excitatory sympathetic } \\
\text { nervous activity. }\end{array}$ \\
\hline $\begin{array}{l}\text { Corticospinal excitability (CSE) } \\
\text { Short intracortical inhibition } \\
\text { (SICI) }\end{array}$ & Unlikely & $\begin{array}{l}\text { Neither CSE or SICI are substantially affected } \\
\text { by SS. }\end{array}$ \\
\hline Persistent inward currents (PICs) & Possible & $\begin{array}{l}\text { SS might adversely affect PIC-dependent } \\
\text { amplification of central drive to the muscle, } \\
\text { consequently reducing maximal force capacity. }\end{array}$ \\
\hline
\end{tabular}

$\Delta$ : change in. 
Table 3. Summary of evidence for/against the effects of morphological factors on the SSinduced force loss.

\begin{tabular}{|lll|}
\hline \multicolumn{1}{|c|}{ Morphological Factor } & Likelihood & \multicolumn{1}{c|}{ Notes } \\
\hline Whole MTU stiffness & Unlikely & $\begin{array}{l}\text { No temporal association between } \Delta \text { MTU } \\
\text { stiffness and } \Delta \text { force. Passive MTU stiffness not } \\
\text { associated with active stiffness. } \\
\text { Passive muscle stiffness }\end{array}$ \\
No data reporting $\Delta$ passive stiffness vs. $\Delta$ force. \\
But $\Delta$ in mechanisms underpinning the $\Delta$ \\
passive stiffness not expected to directly affect \\
force. \\
Tendon stiffness
\end{tabular}

MTU: muscle-tendon unit; PEC: parallel elastic component; $\Delta$ : change in.

Table 4. Summary of evidence for/against the effects of psychological factors on the SS-induced force loss.

\begin{tabular}{|lcl|}
\hline \multicolumn{1}{|c|}{ Psychological Factor } & Likelihood & \multicolumn{1}{c|}{ Notes } \\
\hline \hline Mental energy deficit & Possible & $\begin{array}{l}\text { Since stretch tolerance can induce global ROM } \\
\text { increases but inconsistent evidence exists for }\end{array}$ \\
& & $\begin{array}{l}\text { SS-induced contralateral strength and activation } \\
\text { deficits, it is possible, but not clear, that a prior } \\
\text { mentally fatiguing task such as prolonged SS at } \\
\text { or near the point of discomfort could contribute } \\
\text { to impairments. }\end{array}$ \\
& Likely & $\begin{array}{l}\text { The limited evidence points to prior knowledge } \\
\text { having an effect on subsequent performance. }\end{array}$ \\
\hline
\end{tabular}

$\Delta$ : change in. 
Figure 1: A) The effects of static stretching (SS) with and without a warm-up on performance. B) Mechanisms potentially underpinning the SS-induced performance impairment.

A

\begin{tabular}{l}
$\begin{array}{l}\text { Full warm-up } \\
\text { with <60 s SS } \\
\text { per muscle } \\
\text { group }\end{array}$ \\
$\begin{array}{l}\text { Without } \\
\text { warm-up with } \\
\text { 60 s SS per } \\
\text { muscle group }\end{array}$ \\
$\begin{array}{l}\text { (strength, power, } \\
\text { endurance, sprint }\end{array}$ \\
\hline
\end{tabular}

B

- Possible or $\checkmark$ Likely

× Unlikely or? Unclear

- Mental Energy Deficit

$\checkmark$ Nocebo Effects

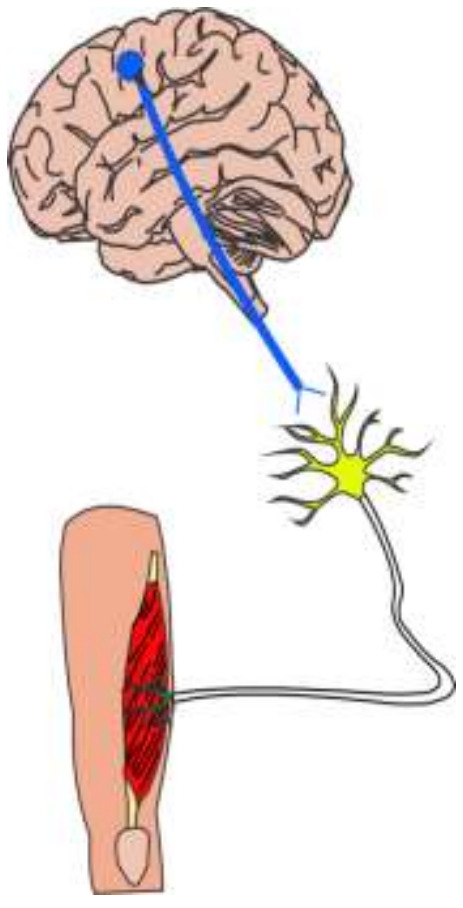

$\times$ Corticospinal excitability

× Cortical silent period

? Hoffman reflex

× Golgi tendon organ inhibition

$-\downarrow$ Exteroceptive reflex

$-\downarrow$ Parallel elastic (muscle)

* Series elastic (tendon) stiffness 